\title{
Soil water stable isotopes reveal evaporation dynamics at the soil-plant-atmosphere interface of the critical zone
}

\author{
Matthias Sprenger, Doerthe Tetzlaff, and Chris Soulsby \\ Northern Rivers Institute, School of Geosciences, University of Aberdeen, Aberdeen, AB24 3UF, UK \\ Correspondence to: Matthias Sprenger (matthias.sprenger@abdn.ac.uk)
}

Received: 14 February 2017 - Discussion started: 21 February 2017

Revised: 4 May 2017 - Accepted: 27 June 2017 - Published: 27 July 2017

\begin{abstract}
Understanding the influence of vegetation on water storage and flux in the upper soil is crucial in assessing the consequences of climate and land use change. We sampled the upper $20 \mathrm{~cm}$ of podzolic soils at $5 \mathrm{~cm}$ intervals in four sites differing in their vegetation (Scots Pine (Pinus sylvestris) and heather (Calluna sp. and Erica Sp)) and aspect. The sites were located within the Bruntland Burn longterm experimental catchment in the Scottish Highlands, a low energy, wet environment. Sampling took place on 11 occasions between September 2015 and September 2016 to capture seasonal variability in isotope dynamics. The pore waters of soil samples were analyzed for their isotopic composition $\left(\delta^{2} \mathrm{H}\right.$ and $\left.\delta^{18} \mathrm{O}\right)$ with the direct-equilibration method. Our results show that the soil waters in the top soil are, despite the low potential evaporation rates in such northern latitudes, kinetically fractionated compared to the precipitation input throughout the year. This fractionation signal decreases within the upper $15 \mathrm{~cm}$ resulting in the top $5 \mathrm{~cm}$ being isotopically differentiated to the soil at $15-20 \mathrm{~cm}$ soil depth. There are significant differences in the fractionation signal between soils beneath heather and soils beneath Scots pine, with the latter being more pronounced. But again, this difference diminishes within the upper $15 \mathrm{~cm}$ of soil. The enrichment in heavy isotopes in the topsoil follows a seasonal hysteresis pattern, indicating a lag time between the fractionation signal in the soil and the increase/decrease of soil evaporation in spring/autumn. Based on the kinetic enrichment of the soil water isotopes, we estimated the soil evaporation losses to be about 5 and $10 \%$ of the infiltrating water for soils beneath heather and Scots pine, respectively. The high sampling frequency in time (monthly) and depth (5 cm intervals) revealed high temporal and spatial variability of the isotopic composition of soil waters, which can be critical, when using
\end{abstract}

stable isotopes as tracers to assess plant water uptake patterns within the critical zone or applying them to calibrate traceraided hydrological models either at the plot to the catchment scale.

\section{Introduction}

Processes in the soil-plant-atmosphere continuum exert a major influence on water partitioning into evaporation, transpiration, and recharge fluxes. Therefore, the outer part of the Earth's terrestrial surface, where the subsurface is closely coupled with the atmosphere and vegetation, is often referred to as the critical zone (Brooks et al., 2015). However, the dynamics of feedbacks between soils and vegetation remain insufficiently understood (Werner and Dubbert, 2016). Consequently, there is an increased interest in improving the conceptualization of the upper boundary of soils, as the important interface between soils-plant-atmosphere. For example, it has been shown that evapotranspiration dynamics can affect travel times of percolating water in the unsaturated zone (Sprenger et al., 2016c; Heße et al., 2017) and catchment outflows (van der Velde et al., 2015; Rinaldo et al., 2011). Additionally, understanding the age distributions of evapotranspiration water has recently gained interest in the literature (Harman, 2015; Soulsby et al., 2016a; van Huijgevoort et al., 2016; Queloz et al., 2015). However, estimates of these evapotranspiration ages and catchment travel times require a sound understanding of the storage and mixing dynamics of the subsurface and surface water pools, which form the sources of evapotranspiration within catchments. Disentangling these atmospheric losses into evaporation and transpiration is particularly challenging. 
Stable isotopes of water $\left({ }^{2} \mathrm{H}\right.$ and $\left.{ }^{18} \mathrm{O}\right)$ are a powerful tool for the analysis of the partitioning of water (see review by Kool et al., 2014). They are often seen as ideal tracers, since they are part of the water molecule. During root water uptake, the isotopic composition of the remaining soil water is usually not altered (Wershaw et al., 1966; Dawson and Ehleringer, 1991). However, evaporation leads to isotopic fractionation, where the remaining water is generally enriched in heavy isotopes (equilibrium fractionation). Additionally, in natural open systems with a humidity of $<100 \%, \delta^{2} \mathrm{H}$ is more likely to be evaporated than $\delta^{18} \mathrm{O}$, because of their different atomic weights, leading to kinetic non-equilibrium fractionation (Craig et al., 1963). Therefore, evaporation losses result in an isotopic signal in the residual water that is distinct from the original isotopic composition of the precipitation waters that were formed in isotopic equilibrium (Dansgaard, 1964).

Such enrichment from kinetic fractionation was found in soil water isotopes across various climatic regions, with more pronounced evaporative signals reaching deeper into the soils in arid and Mediterranean environments than in temperate regions (Sprenger et al., 2016b). However, the temporal variability of the isotopic fractionation in the field has not yet been studied, despite recent technical developments that enabled easier analysis of stable isotopes in soil water (see review by Sprenger et al., 2015a). While Rothfuss et al. (2015) sampled the soil water isotopes in a soil column undergoing evaporation in the laboratory, field studies are usually limited to a few sampling campaigns or a few days (Twining et al., 2006; Gaj et al., 2016; Volkmann et al., 2016). Only recently, Oerter and Bowen (2017) applied in situ soil water isotope measurements to cover almost 1 year, but their study was limited to one particular location. Comparison of the soil water stable isotope dynamics that occur within an entire year at a number of dominant landscape units are yet missing. Additionally, soil water isotopes have been studied much less extensively in the colder regions of the northern latitudes (but see Tetzlaff et al., 2014; Geris et al., 2015a, b). However, the knowledge of soil water isotopic composition is of fundamental importance when studying the root water uptake pattern of plants (Rothfuss and Javaux, 2017). While comparisons of the isotopic signal in soil waters with waters of plant tissues have been reported for decades (see review by Ehleringer and Dawson, 1992), recently posed research questions on which water of the soil's pore system is used by plants (Brooks et al., 2010) are enhancing ecohydrological studies on soil-plant interactions in the critical zone. While studies based on two sampling campaigns (Goldsmith et al., 2012; Evaristo et al., 2016) were supportive of the ecohydrological separation, as presented by Brooks et al. (2010), newly published work with higher temporal resolution of soil water and xylem water isotope sampling suggests that there are seasonal differences with regard to ecohydrological separation (McCutcheon et al., 2016; Hervé-Fernández et al., 2016). A comparative study by Evaristo et al. (2015) showed that the isotopic composition of plant waters - just like soil waters in the upper horizons - are usually kinetically fractionated. However, Evaristo et al. (2015) did not cover the northern latitudes in their review, since there has been only preliminary studies, looking into the root water uptake of the vegetation in this low energy region (Geris et al., 2015a, 2017). Geris et al. (2015a) found relatively little to moderate fractionation in the soil waters at $-10 \mathrm{~cm}$ soil depth and xylem waters in the Bruntland Burn catchment in northern Scotland. However, recent findings about kinetic fractionation in the water pools and tracks of an extended drainage network in a raised bog within the Bruntland Burn showed that evaporation can have a fractionating effect on the stable isotopes of peatland waters, despite the relatively low energy available (Sprenger et al., 2017b). While such isotopic fractionation of open waters in peatlands of the northern latitude were found by others (Carrer et al., 2016; Gibson et al., 2000; Isokangas et al., 2017), the potential fractionation dynamics of the water in the upper soil layer in these cold regions have not previously been studied.

Thus, there is a particular need to better understand such ecohydrological processes in the higher latitudes (Tetzlaff et al., 2013). These environments are known to be especially sensitive to future climate change projections, since relatively little warming could cause intense changes in the water balance when snowfall and snowmelt dynamics (Mioduszewski et al., 2014) and vegetation phenology shift (Shen et al., 2014). The upper soil layers (top $30 \mathrm{~cm}$ ), where about $90 \%$ of the root mass is usually present in the northern temperate and boreal biomes (Jackson et al., 1996), are of special interest to better understand how vegetation influences the partitioning of soil water into evaporation, transpiration, and recharge. The marked seasonality in the northern environments and its impact on the evaporation signal in soil water stable isotopes are fertile areas for investigation.

Here, we address the following research questions in order to improve understanding of the evaporation dynamics at the soil-plant-atmosphere interface and their influences on the water storage and mixing in the critical zone:

- How do precipitation input and the soil water storage mix and affect the soil water isotope dynamics over time?

- How can one infer soil evaporation dynamics in the field from soil water isotopic fractionation?

- How do soil characteristics, vegetation cover, and aspect drive evaporation fractionation dynamics? 


\section{Methods and study sites}

\subsection{Environmental conditions}

Our study was conducted in the Bruntland Burn (BB) experimental catchment $\left(3.2 \mathrm{~km}^{2}\right)$ in the Scottish Highlands; a subcatchment of the Girnock burn, a long-term ecohydrological research site. A detailed description of the soil and vegetation characteristics follows in Sect. 2.3. The underlying geology of the BB is characterized by granitic and metamorphic rocks (Soulsby et al., 2007). About $60 \%$ of the catchment is covered by up to $40 \mathrm{~m}$ of glacial drift deposits which maintain a high groundwater storage (Soulsby et al., 2016b). The climate is temperate-boreal oceanic with mean daily air temperatures ranging between $2{ }^{\circ} \mathrm{C}$ in January and $13^{\circ} \mathrm{C}$ in July. Annual precipitation (P) is about $1000 \mathrm{~mm} \mathrm{yr}^{-1}$, which is fairly evenly distributed and occurs mainly as rainfall (usually $<5 \%$ as snow) of low intensities (50\% of rainfall at intensities of $<10 \mathrm{~mm} \mathrm{~d}^{-1}$ ) (Soulsby et al., 2015). The annual potential evaporation (PET) is about $400 \mathrm{~mm} \mathrm{yr}^{-1}$ and the annual runoff is around $700 \mathrm{~mm} \mathrm{yr}^{-1}$. While the runoff of the BB shows limited seasonality, though lower flows tend to be in summer, the PET estimated with the Penman-Monteith approach follows a strong seasonal dynamic with average PET rates of 0.3 to $0.7 \mathrm{~mm} \mathrm{~d}^{-1}$ from November to February and 2.3 to $2.7 \mathrm{~mm} \mathrm{~d}^{-1}$ from May to August (Sprenger et al., 2017b).

The seasonality of the climate is also reflected in the variability of the isotopic signal of the precipitation with depleted values being more common during winter (dropping frequently below $-80 \% \circ \delta^{2} \mathrm{H}$ from November to March) and more enriched values dominant in summer. The weighted averages for the precipitation isotope signal over 5 years (20112016) were $\mathrm{P}_{\mathrm{avg}} \delta^{18} \mathrm{O}=-8.5 \%$ o and $\mathrm{P}_{\mathrm{avg}} \delta^{2} \mathrm{H}=-61 \%$. The regression between $\delta^{18} \mathrm{O}$ and $\delta^{2} \mathrm{H}$ values of daily precipitation data sampled between June 2011 and September 2016 describes the local meteoric water line (LMWL):

$\delta^{2} \mathrm{H}=7.6 \times \delta^{18} \mathrm{O}+4.7$.

\subsection{Study sites}

Soil sampling focused on four different sites within the BB, where the soils are characterized as freely draining podzols (Fig. 1a). The study sites differed regarding their vegetation cover and their aspect: At two sites, Scots Pine (Pinus sylvestris) forest is the dominant vegetation and at the two other sites, heather (Calluna sp. and Erica sp.) shrubland is dominating (Fig. 1b). Each of the two soil-vegetation landscape units were studied at a north-facing and a south-facing slope (sites had gentle slopes), leading to the following four different sites: north-facing heather $(\mathrm{NH})$, north-facing forest (NF), south-facing heather (SH), and south-facing forest (SF).
The podzols are shallow soils and frequent large clasts within the glacial drift deposit usually inhibit soil sampling below 20 to $30 \mathrm{~cm}$. The soils at the four study sites were relatively similar regarding their color (Fig. 1c) and texture (Table 1). The texture was determined after ignition of the soil samples to free the soil of organic matter content. The coarse and medium sand fractions were determined by dry sieving and the fine sand, silt, and clay fractions were estimated with the hydrometer method (Gee and Bauder, 1986). The soil consist mainly of loamy sand and for $\mathrm{NH}$ and $\mathrm{SH}$, the gravel content as well as the sand content generally increases with depth (Table 1). The bulk density of the podzols in the BB is about $0.74 \mathrm{~g} \mathrm{~cm}^{-3}$ for the top $20 \mathrm{~cm}$ (Geris et al., 2015b).

The organic matter content of the soils was determined for each study site in replicated $5 \mathrm{~cm}$ depth increments $(n=5$ per site and depth) by loss on ignition (LOI) of about $10 \mathrm{~g}$ soil material at $550^{\circ} \mathrm{C}$ in a furnace over $2 \mathrm{~h}$, according to Ball (1964). The LOI decreased linearly with soil depth at all study sites and also showed generally a strong relationship with the gravimetric water content (Table 1). We determined the gravimetric water content (GWC) of all soil samples by relating the weight loss after oven drying at $105^{\circ} \mathrm{C}$ over night to the dry soil mass.

Hemispheric photos taken during the vegetation period revealed that the median of the canopy coverage (CC) of the heather was slightly lower $(\mathrm{NH}: \mathrm{CC}=65 \%, n=9$; SH: $\mathrm{CC}=62 \%, n=9$ ) than for the forested sites (NF: $\mathrm{CC}=67 \%, n=36$; SF: CC $=69 \%, n=46)($ Braun, 2015). The forested sites were both plantations, but with larger trees (mean diameter at breast height $(\mathrm{DBH})=21.8 \mathrm{~cm})$ and lower tree density at $\mathrm{SF}$ compared to $\mathrm{NF}$ (mean $\mathrm{DBH}=13.8 \mathrm{~cm}$ ), where the tree ages were more variable (Braun, 2015). The height of the heather vegetation was limited to about $0.5 \mathrm{~m}$ and tree height was $12-15 \mathrm{~m}$ in the plantations.

Fine root (defined as $0.5-2 \mathrm{~mm}$ according to Zobel and Waisel, 2010) density was determined by wet sieving of the fine roots from soil cores $\left(100 \mathrm{~cm}^{3}\right)$ and subsequent oven drying at $70^{\circ} \mathrm{C}$. This analysis was limited to the heather sites, since the roots and boulders at the forested sites inhibited sampling of undisturbed soil cores. The roots of heather were limited to the upper $15 \mathrm{~cm}$ at the heather sites with almost exponential decrease at $\mathrm{NH}$ and a more linear decrease at $\mathrm{SH}$ (Table 1).

\subsection{Sampling design and analysis}

Soil sampling at each site was conducted at monthly intervals between September 2015 and September 2016 (except for December, February, March; $n=11$ ). For each sampling campaign, soils at all four sites were sampled with a spade across five profiles in $5 \mathrm{~cm}$ increments down to $20 \mathrm{~cm}$ soil depth. For each sampling depth, five replicate samples were taken to account for the high subsurface heterogeneity (Fig. S1 in the Supplement). Each soil sample contained of 


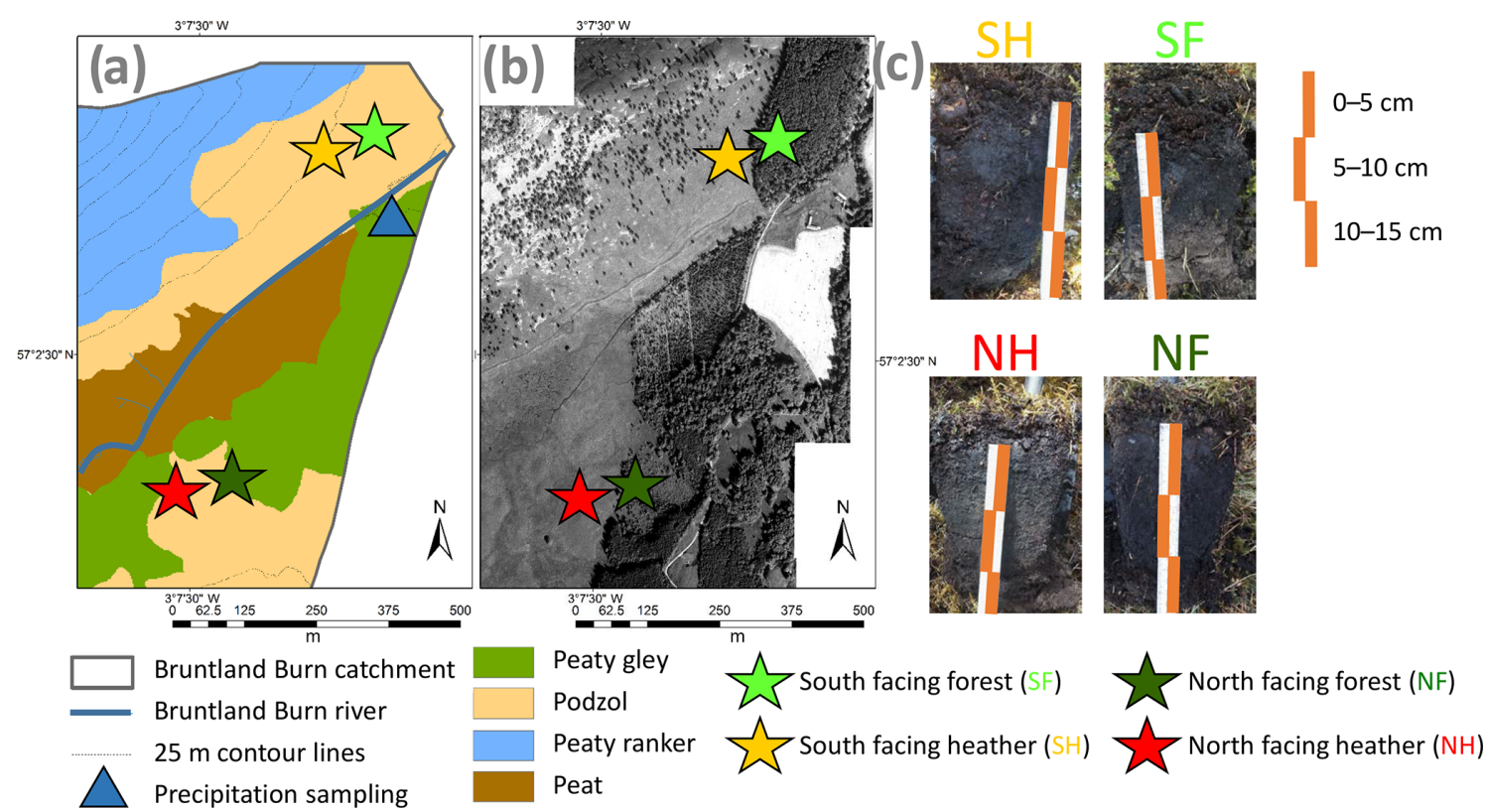

Figure 1. Location of the four sampling sites within the Bruntland Burn catchment on (a) a soil map and (b) an aerial photo. The precipitation sampling location is indicated by a blue triangle in (a). (c) The four photos on the right show exemplary soil profiles for the four study sites.

Table 1. Vegetation and soil profile characteristics of the four study sites: percentage of coarse gravel ( $>20 \mathrm{~mm}$ diameter) and fine gravel (20-2 mm diameter) of the soil sample, percentage of sand (S, 2-0.6 mm), silt ( $\mathrm{Si}, 0.06-0.002 \mathrm{~mm})$, and clay $(\mathrm{C},<0.002 \mathrm{~mm})$ of the fine-soil matrix. Percentage of organic matter content in the soil as loss on ignition (LOI), correlation characteristics for LOI with depth and with gravimetric water content (GWC), and fine root density as percentage of total root mass. Note that for SH, NF, and SF not enough fine soil was left for soil texture analysis after ignition of organic material at $550{ }^{\circ} \mathrm{C}$ and that for $\mathrm{NF}$ and $\mathrm{SF}$, no root density could be measured due to root thickness and stone content. \pm indicate standard deviations out of five replicates for LOI values and range of two and three replicates for root density, respectively.

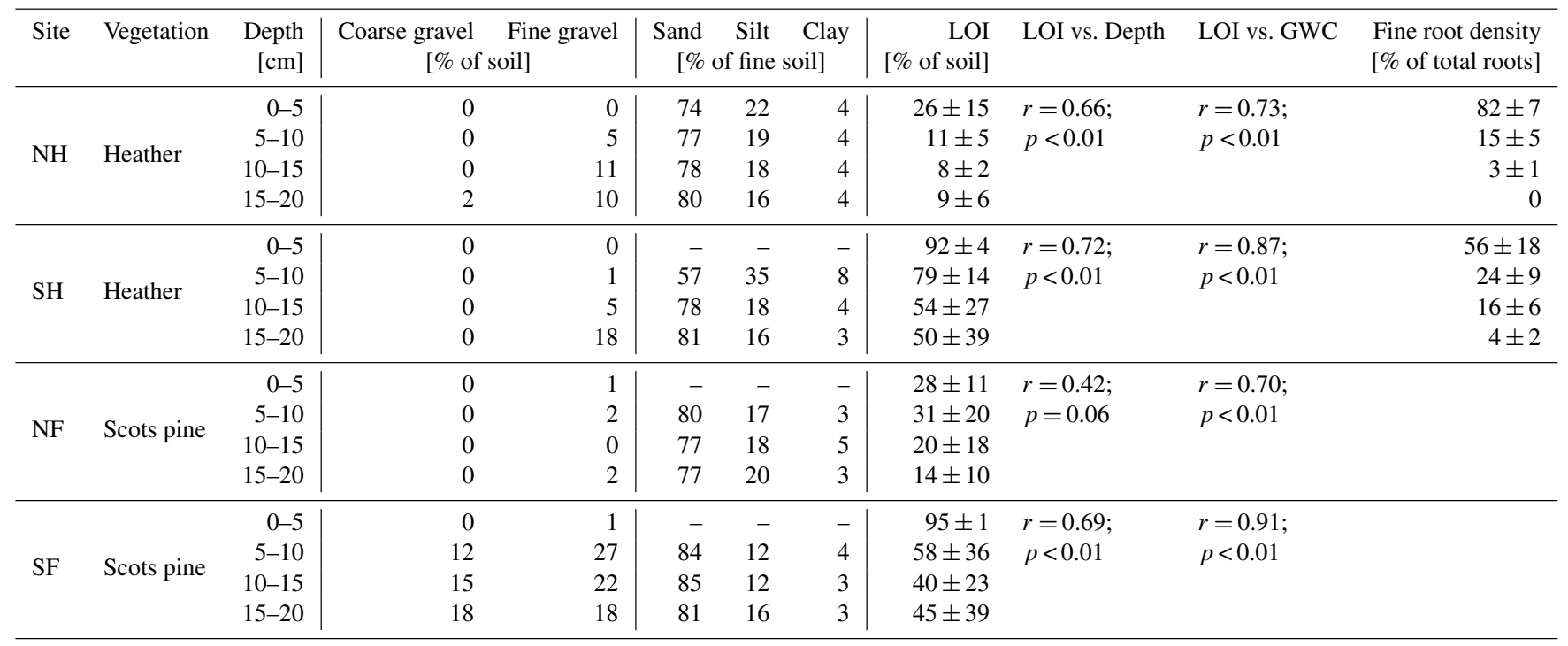

about 80 to $250 \mathrm{~g}$ of soil and was stored in air tight bags (Weber Packaging, Güglingen, Germany), ensuring - by manually furling the bags - that as little air as possible was inside them. The used bags ensured that there were no evaporation losses through bags, since less than $0.15 \%$ of wa- ter was lost over 30 days in an experiment as reported by Sprenger et al. (2015a). For the sampling campaign in May, five additional sites with heather vegetation were sampled on the north- $(n=2)$ and south-facing $(n=3)$ slopes to increase the sample size for comparisons between the two slopes and 
get an idea of the general variability in space. In addition to the monthly sampling, two extra sampling campaigns for the two heather sites were conducted in August (4 and 9 August 2016) to investigate short time changes on both slopes and to further increase the sample number for comparison between the two slopes.

The soil samples were analyzed for their stable isotopic composition $\left(\delta^{2} \mathrm{H}\right.$ and $\left.\delta^{18} \mathrm{O}\right)$ according to the directequilibration method suggested by Wassenaar et al. (2008). The analyses were conducted within 1 week after the sampling to prevent microbial activity within the bags. The analyses were done by adding dry air to the bags that contained the soil samples, heat sealing the bags and letting the soil water equilibrate with the dry atmosphere in the bag for 2 days at constant temperature in the laboratory. The same was done in parallel with bags each filled with $10 \mathrm{~mL}$ of one of three different standard waters covering the range of the soil water isotopic signals: seawater $\left(\delta^{18} \mathrm{O}=-0.85 \% \circ\right.$ and $\left.\delta^{2} \mathrm{H}=-5.1 \% \circ\right)$, Aberdeen tap water $\left(\delta^{18} \mathrm{O}=-8.59 \%\right.$ and $\left.\delta^{2} \mathrm{H}=-57.7\right)$, condensate of distilled tap water $\left(\delta^{18} \mathrm{O}=-11.28 \%\right.$ and $\left.\delta^{2} \mathrm{H}=-71.8\right)$ and for the sampling in January Krycklan snowmelt $\left(\delta^{18} \mathrm{O}=-15.36 \%\right.$ 。 and $\delta^{2} \mathrm{H}=-114.4$ ). After the equilibration over 2 days, the vapor in the headspace of each bag was sampled directly with a needle connected to an off-axis integrated cavity output spectroscopy (OA-ICOS) (TWIA-45-EP, Los Gatos Research, Inc., San Jose, CA, USA). The $\delta^{18} \mathrm{O}$ and $\delta^{2} \mathrm{H}$ composition was continuously measured over $6 \mathrm{~min}$, of which the last $2 \mathrm{~min}$, when the water vapor pressure in the cavity was constant (standard deviation $<100 \mathrm{ppm}$ ), were used to calculate average values. The standard deviation for the $\delta^{18} \mathrm{O}$ and $\delta^{2} \mathrm{H}$ measurements were usually $<0.25$ and $<0.55 \%$, respectively. The standards, which were treated the same way as the soil samples and measured at the beginning, the middle and the end of each sampling day, were then used for calibration to derive the isotopic composition of liquid soil waters from vapor measurements. For a detailed description of the soil water isotope analyses in the lab of the Northern Rivers Institute at the University of Aberdeen with the directequilibration method, we refer to Sprenger et al. (2017a). To assess the precision of the analysis, we derived the standard deviation of in total 81 measurements of the standard Aberdeen tap water sampled along with the soil samples on 27 days of laboratory analyses over 1 year. The standard deviation of the standard water analysis was $0.31 \%$ for $\delta^{18} \mathrm{O}$ values and $1.13 \%$ for $\delta^{2} \mathrm{H}$ values. Recently reported potential effects of $\mathrm{CO}_{2}$ on the isotope analysis of vapor with wavelength-scanned cavity ring-down spectroscopy (Gralher et al., 2016) have been shown to not apply to the OA-ICSO that we used, as shown by Sprenger et al. (2017a). Potentially fractionating effects of interactions between soil water and surfaces of clay minerals (Oerter et al., 2014; Gaj et al., 2017a, b; Newberry et al., 2017) are of minor relevance for our study, since clay contents were low in the sampled soils (Table 1). We can further ensure that the sampled soil volumes always contained much more than $3 \mathrm{~g}$ of water as suggested by Hendry et al. (2015).

In addition to the soil water analysis, precipitation at the field site was sampled with an auto sampler on daily basis at the catchment outlet (location shown in Fig. 1a). The auto sampler was emptied at least every 2 weeks and evaporation from the sampling bottles was prevented by adding paraffin. The precipitation isotopic composition $\left(\delta^{2} \mathrm{H}\right.$ and $\left.\delta^{18} \mathrm{O}\right)$ was determined with the abovementioned OA-ICOS running in liquid mode with a precision of $0.4 \%$ of $\delta^{2} \mathrm{H}$ values and $0.1 \%$ for $\delta^{18} \mathrm{O}$ values, as given by the manufacturer.

\subsection{Data analysis}

We calculated the evaporation line (EL) as a regression line through the soil water isotope data of each sampling date in the dual-isotope space. The EL is characterized by its slope and intercept with the $\delta^{2} \mathrm{H}$ axis. All regressions for EL presented here were significant at the $95 \%$ confidence interval. For each soil water and precipitation sample, we further calculated the line-conditioned excess (lcexcess) as a function of the slope $(a=7.6)$ and the intercept $(b=+4.7 \%$ ) of the LMWL (Eq. 1) as suggested by Landwehr and Coplen (2006):

lc-excess $=\delta^{2} \mathrm{H}-a \times \delta^{18} \mathrm{O}-b$.

The lc-excess describes the deviation of the sample's $\delta^{2} \mathrm{H}$ value the LMWL in the dual-isotope space (Landwehr et al., 2014), which indicates non-equilibrium kinetic fractionation processes due to evaporation after precipitation. Therefore, the lc-excess is similar to the well-established deuteriumexcess (Dansgaard, 1964) that relates the deuterium composition to the global meteoric water line (GMWL). However, we found that lc-excess was advantageous over the deuterium-excess (or single isotope approaches with $\delta^{2} \mathrm{H}$ or $\delta^{18} \mathrm{O}$ ) for inferring evaporation fractionation, because the lcexcess of the precipitation input is about $0 \%$ and with relatively little seasonal dynamics, while $\delta^{2} \mathrm{H}, \delta^{18} \mathrm{O}$, and dexcess can have an intense seasonal variability (Sprenger et al., 2017b). The accuracy for the liquid and soil water isotope analysis result in a precision limit for lc-excess of about 1.1 and $3.4 \%$, respectively.

To infer dynamics of potential evaporation rates, we estimated PET with the Penman-Monteith equation adjusted for the Scottish Highlands by Dunn and Mackay (1995). Note that we focus in our study on the PET dynamics and that the absolute values could vary depending on the aerodynamic and roughness parameter of different vegetation covers. We further did not partition PET into evaporation and transpiration fluxes, since PET was primarily used as a proxy for potential soil evaporation rates, and evaporation and transpiration usually show a linear relationship in temperate regions (Renner et al., 2016; Schwärzel et al., 2009). To understand the potential atmospheric drivers for the soil water isotopic composition, we investigated the effect of antecedent con- 
ditions. We calculated average values of PET over 30 days prior to each sampling campaign $\left(\mathrm{PET}_{30}\right)$ to account for the potential soil evaporation dynamics. Additionally, the precipitation sums and the amount weighted isotopic signal of the daily precipitation isotope samples were computed for the 7 and 30 days period prior to the sampling $\left(\mathrm{P}_{7}\right.$ and $\mathrm{P}_{30}$, respectively) to assess the mixing processes between precipitation input and soil water. Weekly and monthly averages were chosen to see if the relatively young water input or the average over the last month relate differently to the observed soil water isotopic signal.

We estimated the evaporative losses $f$ [\%] based on the Craig-Gordon model (Craig and Gordon, 1965) and formulations introduced by Gonfiantini (1986) for isotope mass balance as follows:

$f=1-\left[\frac{\left(\delta_{\mathrm{S}}-\delta^{*}\right)}{\left(\delta_{\mathrm{P}}-\delta^{*}\right)}\right]^{m}$,

where $\delta_{\mathrm{S}}$ is defined as the average weighted isotopic signal of the soil water in the upper $10 \mathrm{~cm}$. The upper $10 \mathrm{~cm}$ were chosen, because this was the depth with the highest evaporation signal in the soil water isotopes (see results section) and where most evaporation are usually observed in laboratory experiments (Or et al., 2013). $\delta_{\mathrm{P}}$ was defined as the isotopic signal of the original water source by calculating the intercept between the evaporation line of the soil water isotope data in the dual-isotope space (see Fig. S2) and the LMWL according to Javaux et al. (2016). $\delta^{*}$ is the limiting isotopic enrichment factor and $m$ is the enrichment slope, both described by Gibson and Reid (2014) (Eqs. 8 and 9) therein). $\delta^{*}$ is a function of the air humidity $h$, the isotopic composition of the ambient air $\delta_{\mathrm{A}}$, and a total enrichment factor $\varepsilon$ (Gat and Levy, 1978). For humidity, we averaged over 30 days prior to each soil water sampling date the measured humidity at a meteorological station less than $800 \mathrm{~m}$ away from the study sites $h_{30}$. $\delta_{\mathrm{A}}$ was derived as function from the weighted average precipitation input of the 30 days prior to the soil sampling $\delta_{\mathrm{P}_{30}}$ and the equilibrium isotope fractionation factor $\varepsilon^{+}$(Gibson et al., 2008), with the latter depending on the temperature as given by Horita and Wesolowski (1994). We used air temperature data from the aforementioned meteorological station and computed values averaged over 30 days prior to soil water sampling $T_{30}$. The total enrichment factor $\varepsilon$ is the sum of the equilibrium isotope fractionation factor $\varepsilon^{+}$and the kinetic isotope fractionation factor $\varepsilon_{\kappa}$, which is a function of $h_{30}$, the exponent of the diffusion coefficient ratio $n$ and a kinetic fractionation constant, which has a value of $28.4 \%$ or $\delta^{18} \mathrm{O}$ and 25.0 for $\delta^{2} \mathrm{H}$ (Gonfiantini, 1986). Here, we define $n=1$ in accordance to Barnes and Allison (1983), representing diffusional transport in soil pores. The enrichment slope $m$ was calculated as a function from $h_{30}, \varepsilon$, and $\varepsilon_{k}$ in accordance to Welhan and Fritz (1977).

$f$ can be derived either by $\delta^{2} \mathrm{H}$ or $\delta^{18} \mathrm{O}$, indicated as $f_{\delta^{2} \mathrm{H}}$ and $f_{\delta^{18} \mathrm{O}}$. Note that $\delta_{\mathrm{P}_{30}}$ represents in these calculations the net precipitation infiltrating the soil, which has the same iso- topic composition as the measured rainfall isotope values, since no evidence for isotopic enrichment was found for the throughfall and stem flow in heather and Scots pine stands in the Bruntland Burn catchment (Braun, 2015).

Statistical analyses for the soil water isotopes $\left(\delta^{2} \mathrm{H}, \delta^{18} \mathrm{O}\right.$ and lc-excess) for individual sites, depths, and dates were done with non-parametric tests, since the null hypothesis that the data were drawn from a normal distribution was rejected for several sampling campaigns using the Shapiro-Wilk test for normality. We also tested whether there were significant differences between the sites (each site with $n>200$ ) and sampling dates (each date with $n>75$ ) or at different depths (each depth with $n>200$ ) with the Kruskal-Wallis test. When significant differences were present at the $95 \%$ confidence interval, a post hoc Dunn test with $p$ value adjustment "Bonferroni" was applied to see which of the sampling dates or sampling depths were significantly different. For pairwise tests (e.g., aspect (north- and south-facing) or vegetation (soils beneath heather and soils beneath Scots pine; $n>35$ ) for each vegetation type on each sample day and $n>100$ for each vegetation type at each sample depth), the non-parametric Mann-Whitney-Wilcoxon test was used. We assessed if the soil water lc-excess values for different sites were significantly lower than $0 \%$ by using the Wilcoxon signed-rank test.

Mean values for each of the 11 sampling dates of $\delta^{2} \mathrm{H}$, $\delta^{18} \mathrm{O}$, and lc-excess of soil water and $\mathrm{P}_{7}$ or GWC, $\mathrm{PET}_{30}, \mathrm{P}_{7}$, and the lc-excess of $\mathrm{P}_{30}$ were normally distributed according to the Shapiro-Wilk test. Therefore, we used the $t$ test for the mean of one group of samples to test if the average soil water lc-excess deviated significantly from zero for any sampling campaign. We further calculated the Pearson correlation coefficients $(r)$ to describe linear relationships between mean values. Since $\delta^{2} \mathrm{H}$ and $\delta^{18} \mathrm{O}$ of $\mathrm{P}_{30}$ were not normally distributed, the Spearman rank correlation $(\rho)$ was applied to describe relationships with these two variables. For all statistical analyses, the $95 \%$ confidence interval was defined as significance level $(p<0.05)$. Visualizations with box plots generally show the interquartile range (IQR) as boxes, the median as line within the box, the 1.5 IQR as whiskers and data points $>1.5 \mathrm{IQR}$ as points. We further make use of violin plots, where a kernel density estimation of the underlying distribution describing the data is visualized. Statistical differences derived with the post hoc Dunn test are visualized by either letters or colored markers within the box plots, where the same letter or marker color indicate that the samples are not significantly different to each other. Statistical differences between two groups derived with the MannWhitney-Wilcoxon test are indicated by either an asterisk or "X". 
Table 2. For each soil sampling campaign: the PET on that sampling day; PET as average over the 30 days prior to the sampling day (PET 30$)$; lc-excess of the precipitation input weighted averaged over $7\left(\mathrm{P}_{7}\right)$ and $30\left(\mathrm{P}_{30}\right)$ days, respectively; precipitation summed over $7\left(\mathrm{P}_{7}\right)$ and 30 $\left(\mathrm{P}_{30}\right)$ days prior to soil sampling; total soil sample number; minimum, median, maximum, and interquartile range (IQR) of the soil water lc-excess data; slope and intercept of the evaporation line (note that regression is significant at the $99 \%$ confidence interval); and mean gravimetric water content (GWC).

\begin{tabular}{|c|c|c|c|c|c|c|c|c|c|c|c|c|c|c|}
\hline \multirow[b]{2}{*}{ Date } & \multicolumn{2}{|c|}{$\begin{array}{c}\text { PET } \\
{\left[\mathrm{mm} \mathrm{d}^{-1}\right]}\end{array}$} & \multicolumn{2}{|c|}{$\begin{array}{c}\text { P lc-excess } \\
{[\% o]}\end{array}$} & \multicolumn{2}{|c|}{$\begin{array}{c}\mathrm{P} \\
{[\mathrm{mm}]}\end{array}$} & \multirow{2}{*}{$\begin{array}{r}\text { Sample } \\
{[-]}\end{array}$} & \multicolumn{4}{|c|}{$\begin{array}{c}\text { Soil water lc-excess } \\
{[\% o]}\end{array}$} & \multicolumn{2}{|c|}{ Evaporation line } & \multirow{2}{*}{$\begin{array}{r}\text { GWC } \\
{[-]} \\
\text { mean }\end{array}$} \\
\hline & PET & $\mathrm{PET}_{30}$ & $\mathrm{P}_{7}$ & $\mathrm{P}_{30}$ & $\mathrm{P}_{7}$ & $\mathrm{P}_{30}$ & & $\min$. & median & $\max$ & IQR & & & \\
\hline 2015-09-29 & 2.7 & 1.4 & -0.8 & -1 & 1 & 66 & 91 & -16.1 & -5 & 1.1 & 4.2 & 4 & -21.4 & 0.39 \\
\hline $2015-10-20$ & 1.2 & 1.1 & -0.2 & -0.7 & 2 & 60 & 78 & -12.6 & -4.1 & 5.3 & 5.2 & 3.6 & -23.3 & 0.37 \\
\hline $2015-11-26$ & 1.1 & 0.8 & 3.4 & -0.2 & 14 & 94 & 80 & -11.1 & -3 & 6.5 & 3.9 & 4.6 & -21.1 & 0.37 \\
\hline 2016-01-13 & 0.4 & 0.6 & 0.4 & -1.6 & 56 & 434 & 77 & -8.2 & -0.8 & 7.5 & 6 & 8.2 & 10.8 & 0.42 \\
\hline 2016-03-18 & 0.6 & 0.8 & -5.2 & -2.1 & 2 & 33 & 79 & -11.6 & -1.3 & 6.7 & 5.4 & 5.5 & -15.2 & 0.37 \\
\hline 2016-04-27 & 0.9 & 1.2 & 7.3 & -1 & 21 & 80 & 79 & -7.7 & -1.8 & 5.8 & 6.4 & 5.1 & -16.2 & 0.40 \\
\hline $2016-05-24$ & 1.6 & 2.1 & 0.1 & 0.1 & 31 & 66 & 80 & -10 & -1.4 & 2.9 & 3.7 & 4.9 & -17.1 & 0.36 \\
\hline 2016-06-18 & 2.6 & 1.9 & -1.1 & 0.5 & 67 & 105 & 80 & -13.2 & -3.2 & 5.9 & 5.2 & 4.5 & -21.6 & 0.38 \\
\hline $2016-07-26$ & 2.2 & 2.3 & -2.5 & -2.5 & 40 & 98 & 72 & -14.6 & -4.5 & 3.2 & 5.1 & 4.6 & -19.1 & 0.37 \\
\hline $2016-08-23$ & 1 & 2.1 & -3.4 & -3.6 & 12 & 54 & 64 & -16.7 & -6 & 2 & 5.1 & 3.8 & -25.4 & 0.35 \\
\hline 2016-09-23 & 0.4 & 1.9 & 5.3 & -1.6 & 8 & 51 & 77 & -21.7 & -4.1 & 8.9 & 6.2 & 4.3 & -19.9 & 0.33 \\
\hline
\end{tabular}

\section{Results}

\subsection{Temporal dynamics in soil water isotopes}

The temporal dynamic of the seasonally variable precipitation input signal between September 2015 and September 2016 was generally imprinted on the soil water (SW) isotope data at all sites. $\mathrm{P}_{30} \delta^{2} \mathrm{H}$ values usually were most similar to the lowest (most depleted) SW $\delta^{2} \mathrm{H}$ values (Fig. 2b). An exception to this were the soil samples from January, because the sampling took place after a period of intense rainfall $\left(\mathrm{P}_{30}=434 \mathrm{~mm}\right)$ that occurred at the end of December and beginning of January (Fig. 2a). The SW $\delta^{2} \mathrm{H}$ (and $\delta^{18} \mathrm{O}$ ) values averaged over all sites and depths for each sampling campaign correlated significantly with $\mathrm{P}_{30} \delta^{2} \mathrm{H}$ $(\rho=0.92, p<0.01)$ and $\mathrm{P}_{30} \delta^{18} \mathrm{O}(\rho=0.97, p<0.01)$ and $\mathrm{P}_{7} \delta^{2} \mathrm{H}(r=0.74, p=0.01)$, and $\mathrm{P}_{7} \delta^{18} \mathrm{O}(r=0.83, p<0.01)$. However, the soil water averages were usually more enriched than the precipitation input (except for the January sampling). There is relatively little variability in the P lc-excess, which had a weighted average of $-0.58 \%$. The average SW lc-excess was usually more negative than the $\mathrm{P}_{30}$ lc-excess, but the sampling campaigns on 13 January and 18 March in 2016 were an exception (Fig. 2c, Table 2). In contrast to $\delta^{2} \mathrm{H}$ and $\delta^{18} \mathrm{O}$, there was neither a relationship between the SW lc-excess with $\mathrm{P}_{30}$ lc-excess $(r=0.33, p=0.32)$ nor with $\mathrm{P}_{7}$ lc-excess $(r=0.18, p=0.59)$. Thus, the dynamics of SW lcexcess cannot be explained by variation of the lc-excess in the input.

The seasonally variable input of $\mathrm{P} \delta^{2} \mathrm{H}$ and $\delta^{18} \mathrm{O}$ led to significantly more depleted SW isotope values during January and March compared to the other sampling days (indicated by the letter "a" at the box plots in Fig. 3). The sampling in November and April represented a transition period, where the SW isotopic composition was significantly different to the winter and summer samples. The SW $\delta^{2} \mathrm{H}$ and $\delta^{18} \mathrm{O}$ values between May and August did not differ significantly. The soil water samples from January were the only ones that plotted along the LMWL with a slope of the EL of 8.2 (cyan dots in Fig. 3). The other soil water samples followed ELs of slopes between 3.7 and 5.4 with the lowest slopes at end of summer and beginning of autumn (Table 2). The variability of $\delta^{2} \mathrm{H}$ and $\delta^{18} \mathrm{O}$ values was highest for the sampling during winter and generally higher for $\delta^{18} \mathrm{O}$ compared to $\delta^{2} \mathrm{H}$ (note that the axes are scaled according to the GMWL in Fig. 3).

The enrichment in $\mathrm{SW} \delta^{2} \mathrm{H}$ during spring (green dots in Fig. 4a) followed an increase in $\mathrm{PET}_{30}$. The highest $\mathrm{PET}_{30}$ in summer correspond with enriched $\delta^{2} \mathrm{H}$ values. While $\mathrm{PET}_{30}$ decreased at the end of summer, the SW stayed enriched in ${ }^{2} \mathrm{H}$ until late autumn (orange dots in Fig. 4a). Thus, the SW $\delta^{2} \mathrm{H}$ (and also $\delta^{18} \mathrm{O}$, not shown) to $\mathrm{PET}_{30}$ relationship can be described by a linear correlation $(r=0.65, p=0.03$ for $\delta^{2} \mathrm{H}$ and $r=0.64, p=0.03$ for $\delta^{18} \mathrm{O}$ ). However, Fig. $4 \mathrm{a}$ shows that the delayed response in the $\mathrm{SW}$ isotopic signal to changes in $\mathrm{PET}_{30}$ resulted in a hysteresis pattern. The error bars in Fig. 4a, representing standard deviations of all the samples for each sampling campaign, show again that the $\mathrm{SW} \delta^{2} \mathrm{H}$ values were most variable for the sampling in January, becoming less variable during spring and lowest in autumn.

The hysteresis pattern was very pronounced for the relationship between SW lc-excess and $\mathrm{PET}_{30}$, since the SW lcexcess only increased little with onset of $\mathrm{PET}_{30}$ in spring time (green dots in Fig. 4b). During summer, $\mathrm{PET}_{30}$ remained high, and SW lc-excess values became lower and stayed low, even when $\mathrm{PET}_{30}$ started to decrease (Fig. 4b). However, the relationship between SW lc-excess and PET $_{30}$ could statistically be also described by a linear relationship 

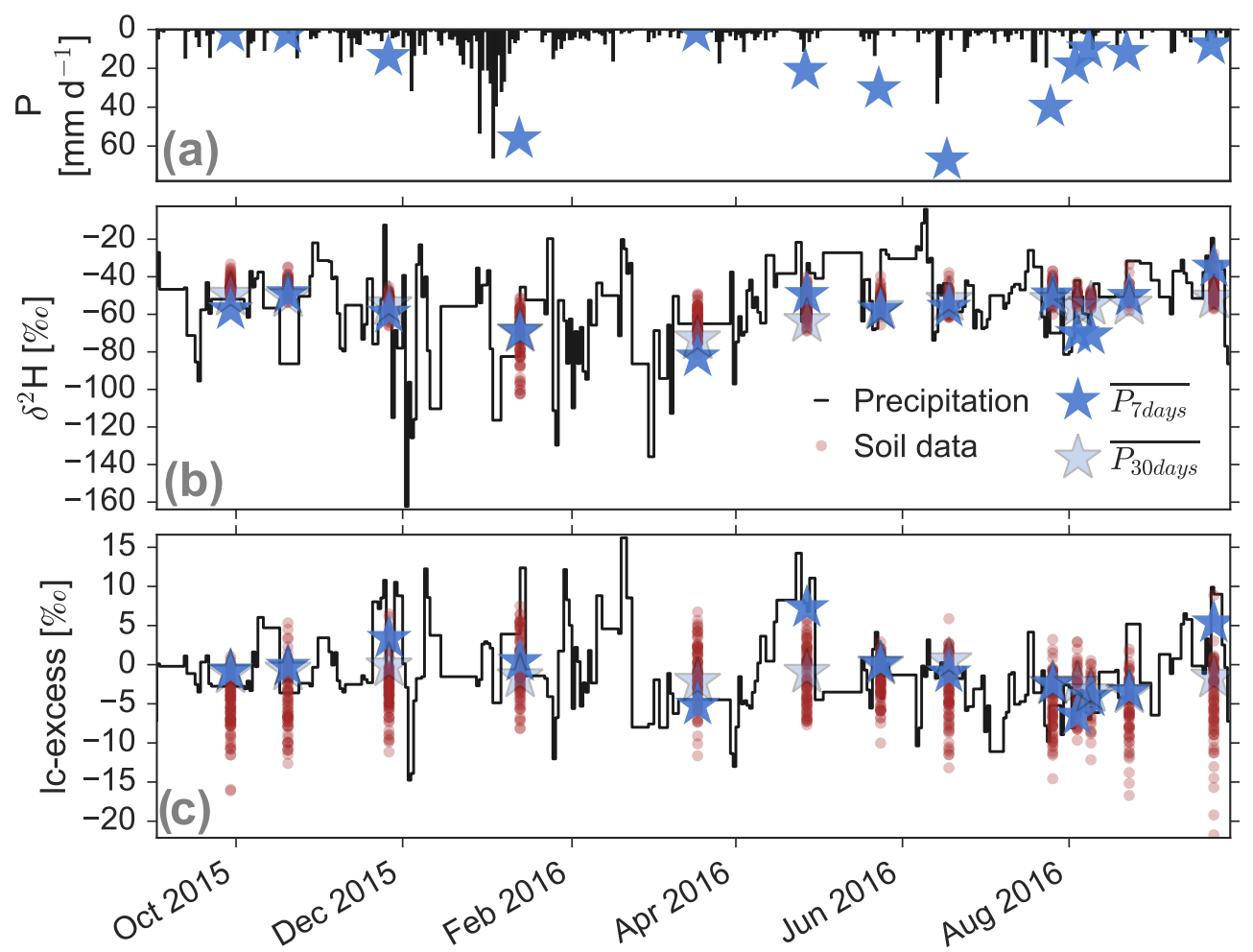

Figure 2. (a) Daily precipitation sums shown in a bar plot and precipitation sums over the 7 days prior to the soil sampling $\mathrm{P}_{7}$ as a blue star. (b) Dynamics of the $\delta^{2} \mathrm{H}$ and (c) lc-excess in the precipitation input (black line) and soil waters (half transparent brown dots). Stars indicate values as weighted averages over 7 days $\left(\mathrm{P}_{7}\right.$, blue $)$ and 30 days $\left(\mathrm{P}_{30}\right.$, light blue $)$ before the day of soil sampling.

$(r=-0.64, p=0.04)$. It is further worth noting that the average SW lc-excess in the upper $20 \mathrm{~cm}$ was for all sampling campaigns, apart from the January sampling, significantly $<0 \%$, $(t$ test, $p=0.63)$. When limiting the analysis to samples from the upper $5 \mathrm{~cm}$, there was also a hysteresis pattern in the relationship between SW lc-excess and $\mathrm{PET}_{30}$.

The average GWC for each sampling campaign correlated significantly with the average SW lc-excess for that sampling day, with lower SW lc-excess when soils were drier $(r=0.67, p=0.02)$. The GWC also correlated with SW $\delta^{18} \mathrm{O}(r=-0.75, p=0.01)$ and $\delta^{2} \mathrm{H}(r=-0.74, p=0.01)$ with isotopically more enriched values when the soil was drier.

\subsection{Spatial soil water isotopes patterns}

\subsubsection{Differences between study sites}

A comparison of the $\mathrm{SW} \delta^{2} \mathrm{H}$ and $\delta^{18} \mathrm{O}$ values within the upper $20 \mathrm{~cm}$ at the sites for different sampling showed no significant differences between the sites (not shown). Differences of the $\mathrm{SW}$ isotope values between sites were limited to the upper $10 \mathrm{~cm}$, with a significantly more depleted $\delta^{2} \mathrm{H}$ signal for soil water at SH compared to NF (at $0-5 \mathrm{~cm}$ ) and SF (at $0-10 \mathrm{~cm}$ ), when looking at values bulked over the entire sampling period (Fig. 5a). For lc-excess, on average soil wa- ter samples at NF and SF showed lower values than NH and $\mathrm{SH}$ and differences were significant between $\mathrm{NF}$ and $\mathrm{SH}$ at $0-5 \mathrm{~cm}$ depth and for NF and SF compared to NH at 5-10 cm depth (Fig. 5b). At all four sites, the SW lc-excess averaged over the upper $20 \mathrm{~cm}$ was significantly $<0 \%$ o between May and October and not significantly $<0 \%$ in January. However, the SW lc-excess for NF and SF was often lower than for $\mathrm{NH}$ and $\mathrm{SH}$ and the lc-excess or NF and SF was significantly $<-5 \%$ for some sampling campaigns, while $\mathrm{NH}$ and SH was usually not significantly $<-3 \%$. Regarding GWC (Fig. 5c), SH had significantly higher values than the other sites and NF had significantly lower values than the other sites in the upper $15 \mathrm{~cm}$. The median GWCs at NH and SF were very similar, but variability was higher in the latter. The GWC was significantly linearly correlated to the organic matter content in the soil (Table 1) at all sites and this relationship explains partly the significant higher GWC at SH. This influence of organic matter content on GWC was evident during each sampling campaign: the sites with higher LOI tended to have higher average GWCs for the 11 sampling days. The coefficients of determination for the relationship between average LOI and average GWC on the sampling day was generally $>0.56$ (blue points in Fig. 6). Note that these coefficients of determination are limited to a sampling number of 4 , given by four sampling sites, while the 


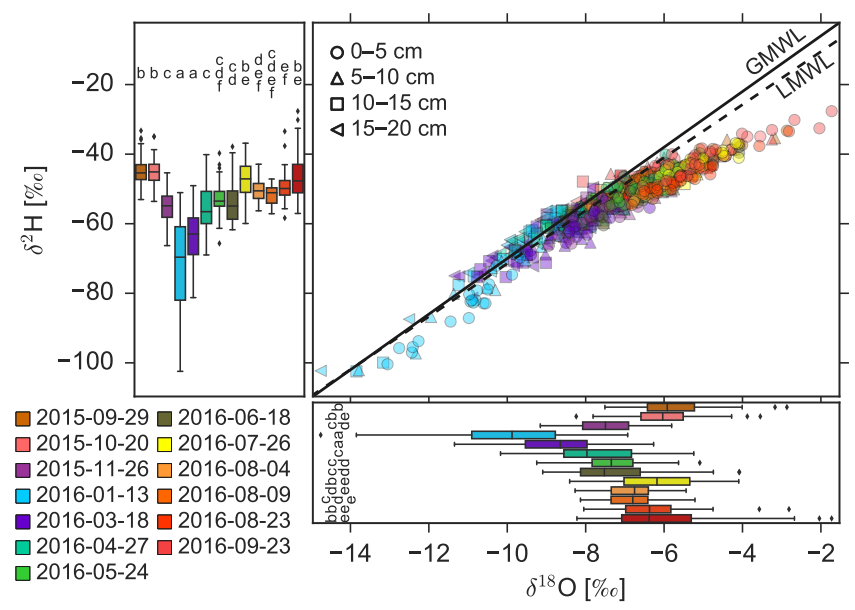

Figure 3. Dual isotope for all soil sampling campaigns and box plots for $\delta^{18} \mathrm{O}$ and $\delta^{2} \mathrm{H}$ bulked over all four sampling sites. The date of each soil sampling is indicated by colors. The depth of the soil samples is shown by different symbols in the dual-isotope plot. Sampling dates that do not have significantly different isotope data according to the post hoc Dunn test are indicated by the same letter next to the box plots. For example, the letter "a" at the box plots from sampling day 13 January 2016 and 18 March 2016, indicate that the soil water isotopes do not differ significantly from each other, but to all other sampling days. The global meteoric water line (GMWL, $\delta^{2} \mathrm{H}=8 \times \delta^{18} \mathrm{O}+10$ ) is shown with a solid line and local meteoric water line (LMWL, $\delta^{2} \mathrm{H}=7.6 \times \delta^{18} \mathrm{O}+4.7$ ) is plotted with a dashed line.

correlations given in Table 1 are based on $n=20$ for each site. This relationship between GWC and LOI persists independently of how many dry days occurred prior to the soil sampling (Fig. 6).

While there was no effect of organic matter content on $\delta^{2} \mathrm{H}$ and $\delta^{18} \mathrm{O}$ values, average LOI at the sites showed a relationship with lc-excess on several sampling dates. These sampling campaigns, when the $r^{2}$ for the relationship between lc-excess and LOI ranged from 0.42 to 0.80 , were all characterized by having at least 13 dry days during the 30-day period $(40 \%)$ prior to the sampling. For sampling campaigns with $>40 \%$ dry days prior to the sampling, there was no relationship between lc-excess and LOI $\left(r^{2}\right.$ ranged between 0.00 and 0.29 , Fig. 6). Therefore, there is a significant correlation between the correlation coefficient between lc-excess and LOI and the percentage of dry days prior to the sampling $(r=-0.84, p<0.01)$.

\subsubsection{Differences with soil depth}

During most sampling dates $\delta^{2} \mathrm{H}$ values became more depleted with increasing soil depth (Fig. 7a; SW $\delta^{18} \mathrm{O}$ very similar and therefore not shown). The $\delta^{2} \mathrm{H}$ values for the top $5 \mathrm{~cm}$ were always significantly different compared to the values at $15-20 \mathrm{~cm}$. The $\delta^{2} \mathrm{H}$ values at $0-10 \mathrm{~cm}$ were for most sampling campaigns significantly enriched compared to the soil water at $15-20 \mathrm{~cm}$. However, during the November and January sampling, the upper $0-5 \mathrm{~cm}$ were more depleted due to the depleted precipitation $\delta^{2} \mathrm{H}$ input (Fig. 1b). The highest variability of SW $\delta^{2} \mathrm{H}$ within the sampling depths was found for the samples taken in January and March. Importantly, the variability of SW $\delta^{2} \mathrm{H}$ generally decreased with soil depth.

The lc-excess for the upper $5 \mathrm{~cm}$ was always significantly more negative than at $15-20 \mathrm{~cm}$ (Fig. 7b). In addition, the soil signature at $5-10 \mathrm{~cm}$ was significantly more negative than at $15-20 \mathrm{~cm}$; exceptions were November 2015 at $0-5 \mathrm{~cm}$ and September 2016 at $5-10 \mathrm{~cm}$. The lc-excess depth profiles had a persistent pattern of steadily decreasing lc-excess values with depth, approaching SW lc-excess of $0 \%$ at $15-20 \mathrm{~cm}$ depth. The SW lc-excess variability usually decreased with depth, but not for the November sampling (Fig. 7b).

SW lc-excess at $15-20 \mathrm{~cm}$ was usually not significantly $<0 \%$, but at the top $5 \mathrm{~cm}$, the SW lc-excess was significantly lower $<0 \%$ o throughout the year; with only few exceptions (January and April 2016, Fig. 7).

The upper $5 \mathrm{~cm}$ soil had always significantly higher GWCs than the soil between 15 and $20 \mathrm{~cm}$ depth. This pattern of decreasing soil moisture with depth was persistent over time. The range of the GWC was always much lower below $15 \mathrm{~cm}$ than above (Fig. 7).

\subsubsection{Differences due to vegetation cover}

Comparing all soil samples bulked over depth and sampling campaigns, SW beneath Scots pine was significantly more enriched in $\delta^{2} \mathrm{H}$ (Mann-Whitney-Wilcoxon Test, $p=0.038$ ) and $\delta^{18} \mathrm{O}(p=0.0062)$ than the SW beneath heather sites. In addition, lc-excess was significantly lower for the SW at the forested sites compared to the heather sites $(p<0.01)$.

The temporal dynamics of the differences of $\delta^{2} \mathrm{H}$ (and also $\mathrm{SW} \delta^{18} \mathrm{O}$, but not shown) values for SW beneath the different vegetation sites show that the SW beneath Scots pine was (except for the sampling in March for $\delta^{2} \mathrm{H}$ ) always more isotopically enriched than the soil water beneath heather (Fig. 8a). However, the differences were only significantly different for 4 out of the 11 sampling campaigns. SW $\delta^{2} \mathrm{H}$ values showed usually higher variability for soils beneath Scots pine for the sampling campaigns between May and October, but during winter, the variability is generally high for soils beneath both vegetation types.

The SW lc-excess was - except for the January and May sampling campaigns - more negative in the soils beneath Scots pine compared to soils beneath heather (Fig. 8b). The GWC was also always lower in the soils beneath Scots pines. These differences were most pronounced at the end of the summer and during autumn (Fig. 8c).

The differences between the SW isotopic composition under the two different vegetation types mainly stemmed from differences in the shallow soils. Despite being classed as similar podzolic soils, the SWs beneath Scots pine were significantly more enriched in the upper $10 \mathrm{~cm}$ in $\delta^{2} \mathrm{H}$ (and also 

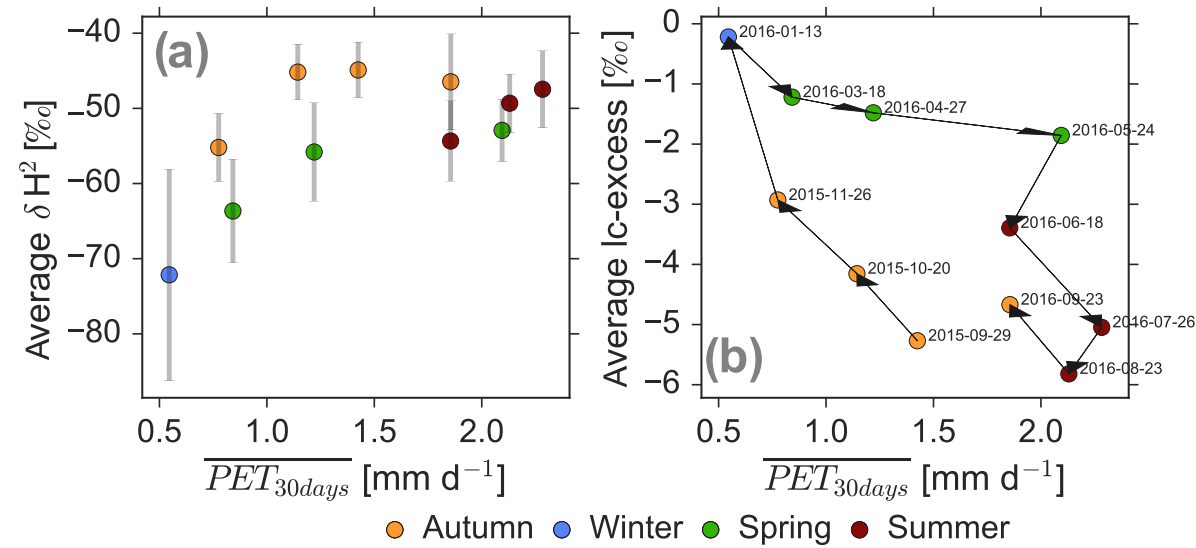

Figure 4. Variation of the (a) $\delta^{2} \mathrm{H}$ and (b) lc-excess in the top $20 \mathrm{~cm}$ of the soil as a function of the potential evaporation averaged over the 30 days prior to the sampling day $\left(\mathrm{PET}_{30}\right)$. The colors of the scatter points indicate the season of the sampling. The error bars in (a) indicate the standard deviation of $\delta^{2} \mathrm{H}$ in the soil waters. The arrows in (b) indicate the order of sampling and sampling dates are given.
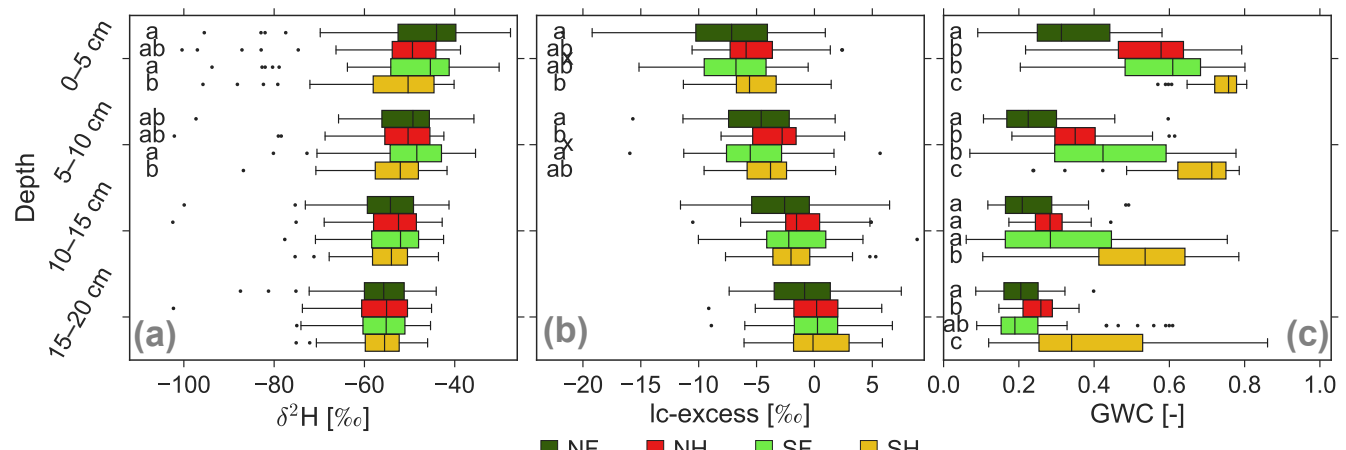

Figure 5. Site specific (a) $\delta^{2} \mathrm{H}$, (b) lc-excess, and (c) gravimetric water content (GWC) for the soils at the four study sites summarized for each site over all sampling dates as function of depth. For depths, where letters are shown, different letters indicate significant differences between the sites for the specific depth.

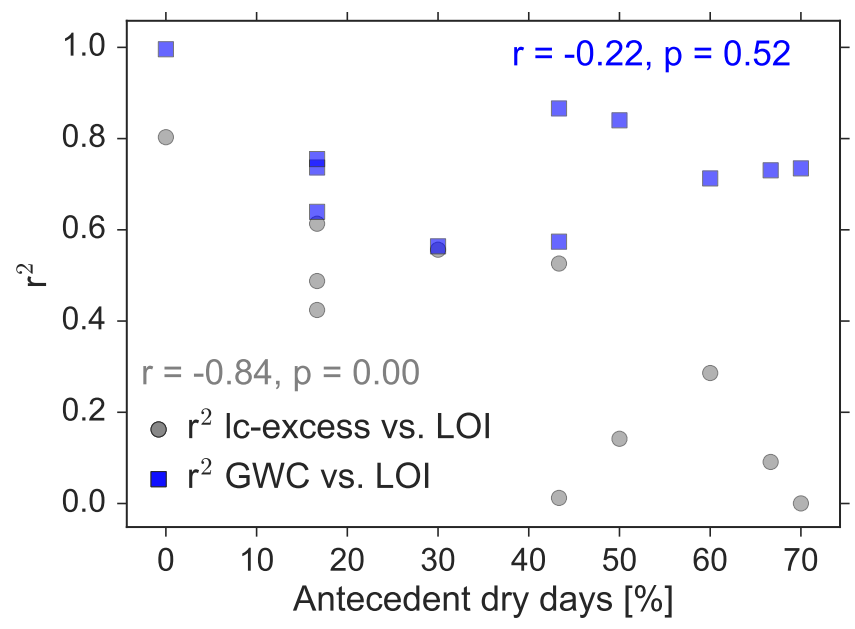

Figure 6. Relationship between coefficient of determination of the relationship between lc-excess and LOI (gray) and GWC and LOI (blue) with the percentage of dry days during the 30-day period prior to the soil sampling. $\delta^{18} \mathrm{O}$, not shown) than the SW beneath heather (Fig. 9a). SW beneath Scots pine had a significantly more negative lcexcess signal for the upper $15 \mathrm{~cm}$ soils. The GWC of soil beneath Scots pine were over the entire soil profile significantly lower than for the soils beneath heather (Fig. 9b).

No significant differences were found when splitting the samples according to their aspect. There were neither differences when looking at all sampling depths, nor for any individual sampling depth (not shown). A comparison of the more intensive spatially distributed sampling focusing on the top $10 \mathrm{~cm}$ of heather soils in May 2016 at the north-facing sites $(n=26)$ and south-facing sites $(n=33)$ showed also no significant differences between aspects regarding isotopes and soil moisture. Increasing the sampling numbers for the heather sites when the two additional sampling campaigns in August were included, also did not result in significant differences between the two studied slopes. The median SW $\delta^{2} \mathrm{H}$ values for the samples taken at the south- and north-facing slopes were -50.6 and $-50.9 \%$, respectively. The median SW lc-excess was -3.4 and $-3.3 \%$ for south- and north- 

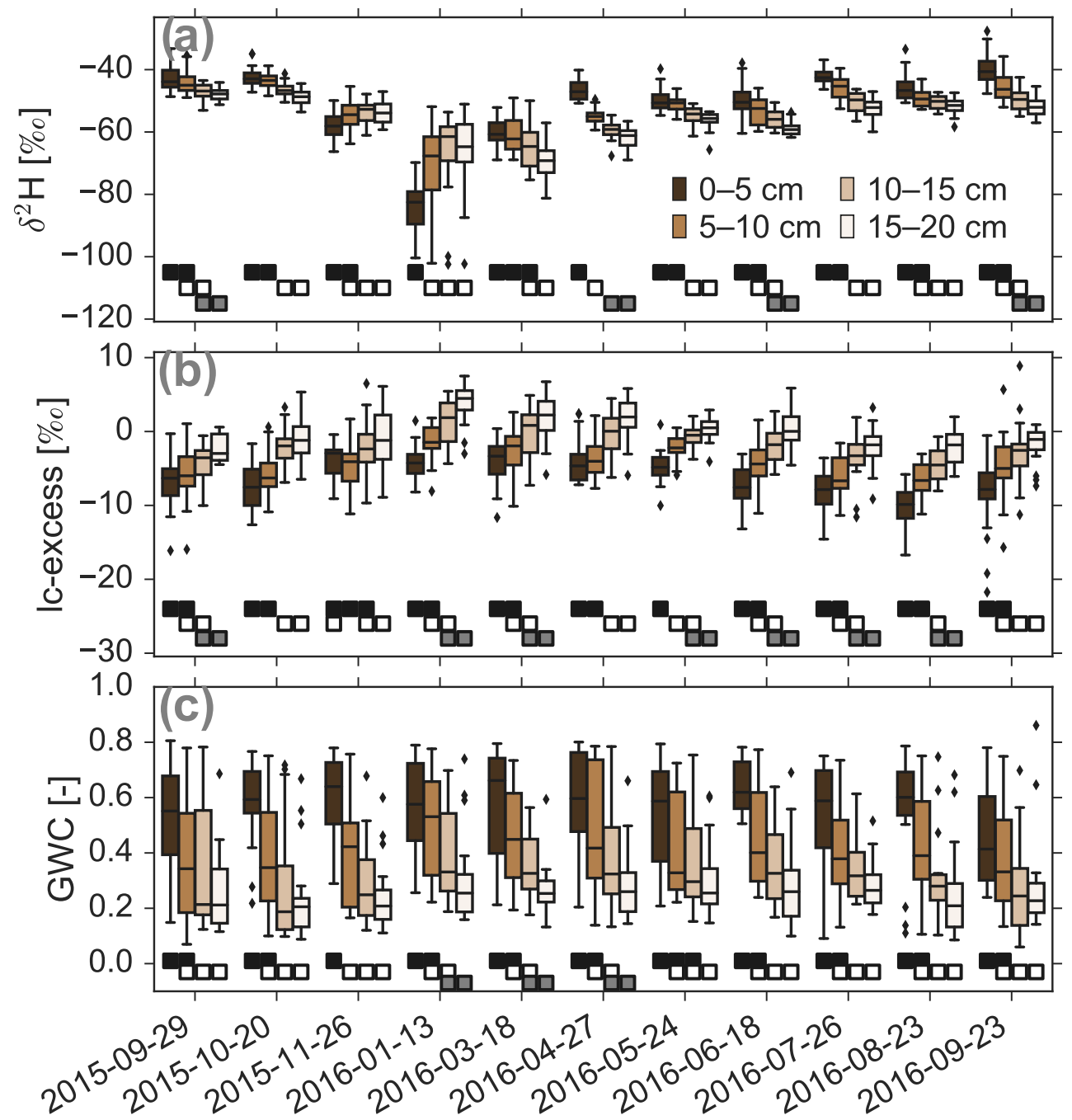

Figure 7. Differences of (a) $\delta^{2} \mathrm{H}$, (b) lc-excess, and (c) gravimetric water content (GWC) over depth for each sampling day. Black, white, and gray squares below the box plots indicate significant differences between the depth for each sampling day according to the Dunn test (i.e. same color reflects similarities; different colors differences). For example, for 29 September 2015, samples from 0 to $5 \mathrm{~cm}$ depth were significantly different from samples from the depth $10-15 \mathrm{~cm}$ and $15-20 \mathrm{~cm}$, but not significantly different to samples from 5-10 cm depth.

facing slope, respectively. The median GWC was 0.62 and 0.54 for the samples at the south- and north-facing slope, respectively.

\subsection{Evaporation estimates}

Our findings clearly showed an influence of the vegetation on the evaporation signal in the soil water between April and October. Therefore, we estimated the fraction of evaporation losses in the SW beneath Scots pine and heather as described in the methods section for the nine samplings in this period. For the heather sites, the median $( \pm \mathrm{SD}$ over the period) values of $f_{\delta^{2} \mathrm{H}}$ and $f_{\delta^{18} \mathrm{O}}$ were $5.0 \pm 4.0$ and $3.7 \pm 1.6 \%$, respectively, and for the forested sites, the values were $f_{\delta^{18} \mathrm{O}}=9.9 \pm 3.4 \%$ and $f_{\delta^{2} \mathrm{H}}=6.3 \pm 2.1 \%$. Thus, the SW fractionation signal indicates that about 8 and $4.5 \%$ of the originally infiltrated water (with lc-excess $=0 \%$ ) went back into the atmosphere by soil evaporation.

\section{Discussion}

\subsection{Mixing of precipitation input and the critical zone water storage}

Our uniquely detailed data set from 11 sampling campaigns over 1 year revealed the isotopic response of soil water to variable precipitation inputs. An understanding of the isotopic variability of the precipitation input signal is crucial for the interpretation of the soil water isotopes in terms of soil evaporation dynamics at the soil-plant-atmosphere interface. Therefore, we will first discuss how mixing of the 

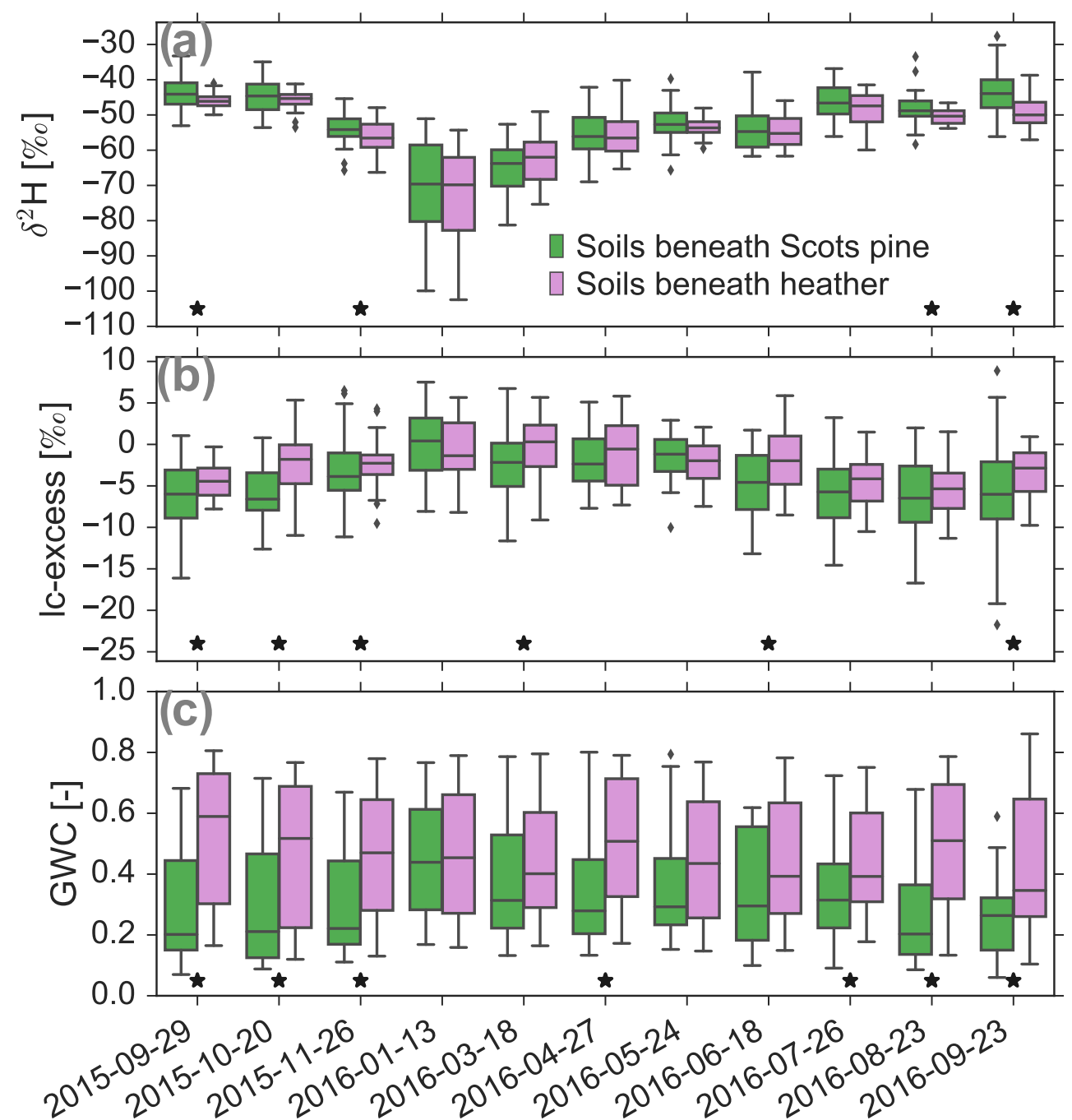

Figure 8. Differences of (a) $\delta^{2} \mathrm{H}$, (b) lc-excess, and (c) gravimetric water content (GWC) for soils under Scots pine (green) and soils under heather (violet) during 1 year. Significant differences estimated with the Mann-Whitney-Wilcoxon test between soils under Scots pine and soils under heather for a particular day are indicated by a star.

infiltrating precipitation within the topsoil provides the basis for the isotopic enrichment in the soil due to evaporative losses.

Given that the soil at the four sites consists of similar texture, it is not too surprising that the SW generally responded similarly to the seasonal $\mathrm{P} \delta^{2} \mathrm{H}$ and $\delta^{18} \mathrm{O}$ input signal. However, we would expect differences in the soil physical properties due to the differences in the organic matter contents. Our data showed that higher organic matter resulted in higher GWCs at the sites. That means that the soil water storage is higher for the sites with higher organic material, which is in line with several other studies (e.g., Hudson, 1994).

While this relationship between GWC and LOI persisted independently of how many dry days occurred prior to the soil sampling, LOI showed a relationship with lc-excess depending on the dryness. This suggests that during dry pe- riods, the external atmospheric drivers such as evaporative demand may have a high influence on the SW lc-excess. In contrast, during wet periods, the soil water storage capacities - here, mainly controlled by organic material - gain importance. With increasing new precipitation input (lc-excess close to zero), the sites with higher organic matter content have a different SW lc-excess than the sites with lower organic matter content, because there is a higher mixing volume for the sites with the high LOI compared to the soils with lower LOI (Fig. 6). Hence, future and current changes in the organic matter content of soils with high organic matter, due to, for example, land use or climate changes (Foley et al., 2005; Rees et al., 2011), would have an impact on the mixing of event and pre-event water in the podzols.

Interestingly, the highest variability of the $\delta^{2} \mathrm{H}$ values in the soil water was found for the sampling after the intense 


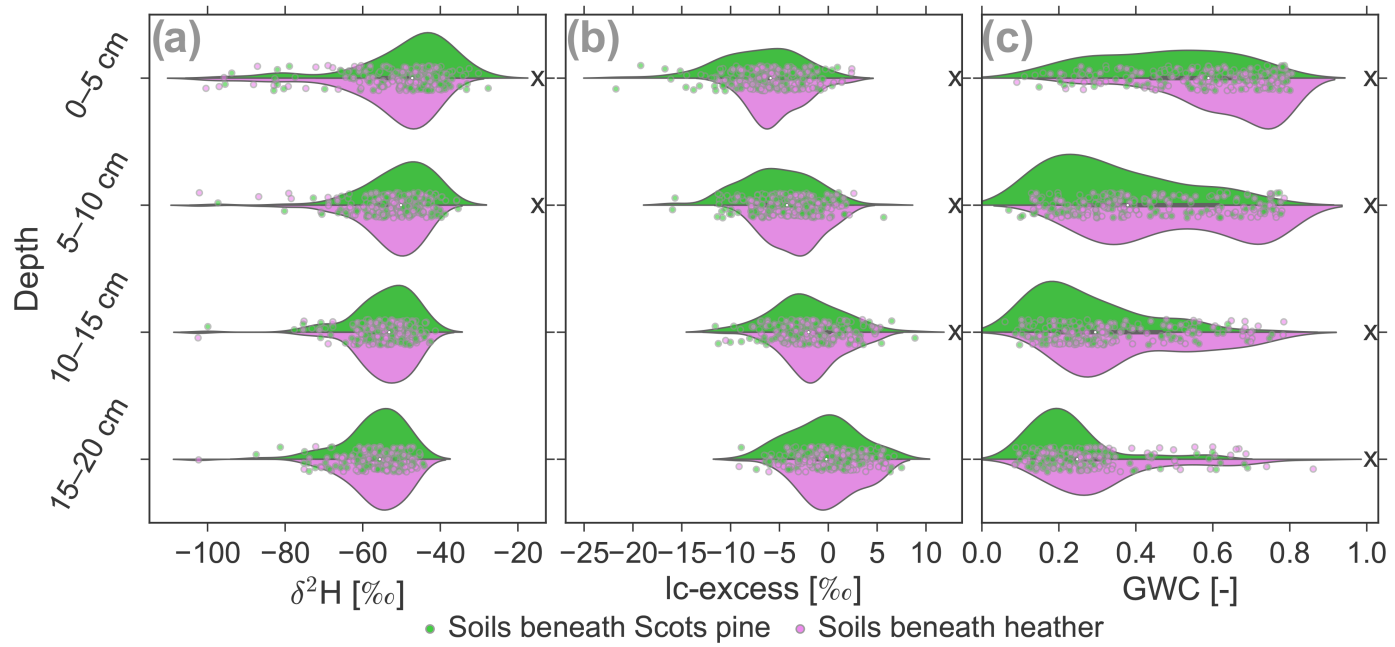

Figure 9. Violin plots showing the distribution as a kernel density estimation of the soil water (a) $\delta^{2} \mathrm{H}$, (b) lc-excess, and (c) gravimetric water content over all sampling campaigns with differentiation between soils beneath Scots pine (green) and soils beneath heather (purple). The symbol "X" at the depths indicates significant differences between the soils under Scots pine and soils under heather for the particular depth as estimated with the Mann-Whitney-Wilcoxon test. Dots indicate the individual sample points.

rainfalls in January 2016 (Figs. 4a, 7a), which indicates that the unsaturated zone was not homogeneously wetted by the exceptionally high precipitation input. This suggests that bypass flow occurred and the stored soil water was not necessarily well-mixed. However, the significantly lower $\delta^{2} \mathrm{H}$ values in the top $5 \mathrm{~cm}$ indicate that, despite the potential occurrence of preferential flow, most of the depleted precipitation input was stored in the very top soil and the more enriched soil water from autumn was partly mixed with and partly replaced by the event water. The sampling in January was also special, because the GWC was about as high in the soils beneath Scots pine than in the soils beneath heather. Hence, differences in GWC between soils beneath the two vegetation types during the vegetation period as discussed below would stem from different transpiration and soil evaporation rates and not from differences in the soil water storage capacities.

The higher variability of the $\mathrm{SW} \delta^{2} \mathrm{H}$ values beneath Scots pine compared to the SW beneath heather (Fig. 9) cannot be explained by differences of the throughfall isotopic signal, since they are minor for the two vegetation types (Braun, 2015). The higher variability in the isotopic signal therefore indicates that flow paths are generally more variable in the forest soils. This is probably due to preferential flows via larger macropores formed by tree roots that also reach deeper than the shallower roots of heather. While the high variability of SW $\delta^{2} \mathrm{H}$ values indicate preferential flow paths, there was also a clear signal that much of the input water percolates through the pore matrix, since we see that the depleted winter precipitation signal is still evident at $-20 \mathrm{~cm}$ soil depth during the March sampling campaign (Fig. 7a).

The relatively high soil water storage volumes in the podzols result in a damping of the $\delta^{2} \mathrm{H}$ signal in the SW com- pared to the precipitation input. There was also a more damped isotopic signal with soil depth due to increased mixing and cumulatively larger soil water storage. Because of this damping effect, the differences between the sites (Figs. 5a, 9a) and sampling times (Fig. 7) decreased with depth.

Our data support the findings of Geris et al. (2015b), who showed - with soil water samples extracted with suction lysimeters - a more damped signal in deeper layers of the soils beneath heather than beneath Scots pine. However, we did not see a more delayed response beneath Scots pine compared to podzols beneath heather as observed by Geris et al. (2015b). This discrepancy could arise from the fortnightly sampling frequency by Geris et al. (2015b) and monthly sampling frequency in the current study, as well the effect of an unusually dry summer in the former study.

In contrast to Geris et al. (2015b), who sampled the soilvegetation units with duplicates, our sampling design with five replicates allowed for a clearer assessment of the spatial heterogeneity of the subsurface. For example, the standard deviation of the SW $\delta^{2} \mathrm{H}$ and $\delta^{18} \mathrm{O}$ values for the $5 \mathrm{~cm}$ depth increments at each site was - for the entirely sampled upper $20 \mathrm{~cm}$ of soil - always higher than the measurement accuracy of 1.13 and $0.31 \%$, respectively. At Bruntland Burn as in most northern temperate and boreal biomes (Jackson et al., 1996) - topsoils contain almost all the root biomass. For the interpretation of potential sources of root water uptake this means that the uncertainty of the potential water source signal - caused by the heterogeneous isotopic composition at particular depths within the rooting zone - is higher than the measurement errors. Our field measurements underline, therefore, the need for an improved spatial resolution of soil water sampling when studying root water uptake pat- 
terns with stable isotopes, as recently called for by Berry et al. (2017). Further, this high variability will potentially impact the application of soil water isotopes for the calibration of soil physical models and the resulting interpretation (Sprenger et al., 2015b).

The observed mixing processes have implications for modeling of water movement within the critical zone. The soil water isotope response seems to follow a replacement of the pore waters by a mixture of newly infiltrated precipitation and older water, which could probably be described by the advection dispersion equation as frequently applied for isotope modeling in the unsaturated zone (Adomako et al., 2010; Stumpp et al., 2012; Mueller et al., 2014; Sprenger et al., 2015b). However, during intense rainfall, the precipitation input seems to partly bypass the matrix leading to rapid changes in the tracer signal in the subsoil and a generally high variability of the soil water isotopes within the entire soil profile. Such preferential flow processes might be better represented by soil physical models that take different mobility of water within the pore space into account, like the dual-permeability (Gerke and van Genuchten, 1993) or dualporosity (van Genuchten and Wierenga, 1976) approaches. For example, Gouet-Kaplan et al. (2012) showed with column experiments that a significant amount of pre-event (or "old") water stayed in a sandy pore system. They found that these processes could be described by a dual-porosity (mobile-immobile) model. Such incomplete mixing within the unsaturated zone could have an impact on catchment transit time estimates (van der Velde et al., 2015). Given the high storage volumes of the periglacial deposits (Soulsby et al., 2016b) and the high water-mixing volume in the riparian zone (Tetzlaff et al., 2014) in the Bruntland Burn, it is yet unclear, which role the relatively slow moving and partly mixed soil waters in the soil matrix at the hillslopes could play regarding long tails of transit times in the Scottish Highlands, as reported by Kirchner et al. (2010).

\subsection{Evaporation dynamics within the soil-plant-atmosphere interface}

The correlation between the seasonally variable $\mathrm{P}$ and $\mathrm{SW}$ isotopic signals inhibited an assessment of soil evaporation processes from either $\delta^{2} \mathrm{H}$ or $\delta^{18} \mathrm{O}$. Instead, the SW lc-excess values were independent from the $\mathrm{P}$ input and were therefore indicative of kinetic fractionation due to soil evaporation. The monthly soil water sampling revealed soil evaporation dynamics (in terms of lc-excess) during times of the highest potential evaporation for the Scottish Highlands. The evaporation fluxes were not expected to be high given the relatively low energy environment at the study site. The soil waters showed, nevertheless, a clear fractionation signal in terms of their lc-excess (25th percentile $<-6 \%$ o between June and October) and the evaporation line (3.6 and 4.5 between June and October, Table 2). This fractionation signal in the soil water was of the same magnitude as for surface wa- ters in the peatland drainage network of a raised bog in the Bruntland Burn, where the lc-excess reached values $<-5 \%$ and the EL slope ranged from 3.9 to 4.9 between May and September (Sprenger et al., 2017b). In comparison to arid and Mediterranean environments, where SW lc-excess can fall below $-20 \%$ (McCutcheon et al., 2016, and reviewed in Sprenger et al., 2016b), the SW lc-excess in the Scottish Highlands remained relatively high. While the lc-excess was usually not significantly different from zero at $15-20 \mathrm{~cm}$ soil depth in the studied podzols of the study site, soils studied by McCutcheon et al. (2016) in a much drier environment (Dry Creek, Idaho) showed that the SW lc-excess from the surface down to $-70 \mathrm{~cm}$ was significantly lower than zero.

The high soil water storage contributes to the SW lc-excess dynamics shown in the hysteresis pattern for the relationship between SW lc-excess and $\mathrm{PET}_{30}$, which revealed that there was a delayed response of the SW lc-excess to the onset and offset of soil evaporation in spring and autumn, respectively. We explain the hysteresis by generally low soil evaporation fluxes, relatively high humidity in the Scottish Highlands, and high soil water storage. The high soil water storage means that relatively high evaporation losses are needed in spring to change the ${ }^{2} \mathrm{H}$ to ${ }^{18} \mathrm{O}$ ratios by kinetic fractionation. The variability of SW lc-excess values from July to September was relatively small, indicating that a steady state between soil water fractionation by soil evaporation and input of unfractionated precipitation was reached. In autumn, when the soil evaporation ceased, relatively high unfractionated precipitation input was needed to dilute the evaporation fractionation signal of the soil water again (Fig. 4).

In contrast to our findings of a pronounced evaporation fractionation in the soil water, Geris et al. (2015b), who sampled the mobile soil water for its isotopic composition with suction lysimeters, saw little to no fractionation. The sampling by Geris et al. (2015b) took place at the same/similar sites (podzols beneath Scots pine and heather within the Bruntland Burn), but during different years. However, the sampling period of Geris et al. (2015b) covered summer 2013 , which was exceptional dry ( $\sim 10$-year return period) and would have been therefore very likely to induce evaporation fractionation in soil waters. We conclude that the differences between the two studies most likely relate to the different sampling methods. Suction lysimeters, as applied by Geris et al. (2015b), are known to be limited to sample the mobile water within the pore space, but the directequilibration method applied in our study also samples more tightly bound waters (Sprenger et al., 2015a). Consequently, we can infer that the mobile waters sampled with suction lysimeters will be relatively young waters that percolated without experiencing pronounced water losses due to soil evaporation. In contrast, the soil water data presented in our study represent a bulk pore water sample, where more tightly bound waters will be integrating older ages and, therefore, affected by kinetic fractionation during periods of atmospheric evaporative demand. However, comparisons be- 
tween mobile and bulk soil water isotopic signals showed that tightly bound water at soil depth deeper than $10 \mathrm{~cm}$ was usually more depleted than the mobile waters during spring or summer, due to filling of fine pores of a relatively dry soil with depleted precipitation several months earlier (Brooks et al., 2010; Geris et al., 2015a; Oerter and Bowen, 2017). Our study shows that, in contrast to old isotopically distinct infiltration water, also the legacy of evaporation losses over previous months allows for separation between pools of different water mobility in the soil-plant-atmosphere interface. This means that old (more tightly bound) water might have not only a distinct $\delta^{2} \mathrm{H}$ or $\delta^{18} \mathrm{O}$ signal compared to mobile water due to seasonally variable precipitation inputs, but also an evaporative enrichment signal from periods of high soil evaporation. In conclusion, when relating isotope values of xylem water to soil water to study root water uptake patterns, an evaporation signal (that is lc-excess of xylem water $<0$ ) would not be paradoxical, but simply represent the range of available soil water in the subsurface.

So far, mostly cryogenic extraction was used to analyze the isotopic composition of bulk (mobile and tightly bound) soil waters and relate these data to, for example, root water uptake pattern. However, recent experimental studies indicated potential for fractionation during the cryogenic extraction (Orlowski et al., 2016), probably induced by watermineral interactions (Oerter et al., 2014; Gaj et al., 2017a, b). The direct-equilibration method - as a potential alternative analysis method - we applied in our study was so far usually limited to study percolation processes (e.g., Garvelmann et al., 2012; Mueller et al., 2014; Sprenger et al., 2016a). To our knowledge, only Bertrand et al. (2012) used the directequilibration method to study the water use by plant water use and the influence of evaporation fractionation, but they bulked the soil data of the upper $20 \mathrm{~cm}$.

However, our results emphasize the importance of sampling the upper most soil layer when studying plant-water interactions and soil evaporation dynamics. The evaporation was predominantly taking place at the interface to the atmosphere, where the lowest SW lc-excess values were found throughout the sampling period. Due to the relatively wet conditions of the studied soils, the evaporation signal dropped sharply within the first $15 \mathrm{~cm}$ soil depth and was always significantly lower at the top $5 \mathrm{~cm}$ compared to the SW at 15-20 cm depth. Geris et al. (2015a) sampled with cryogenic extraction the isotopic composition of the bulk soil water at $-10 \mathrm{~cm}$ soil depth at the site NF during the summer of 2013. They found soil water isotopes of the same magnitude at $-10 \mathrm{~cm}\left(\delta^{2} \mathrm{H}\right.$ between -40 and $-55 \%$ ), but their sample size was too little to assess evaporation fractionation patterns.

The pronounced differences of the soil water samples in the dual-isotope space over little soil depth is crucial when assessing potential water sources of the vegetation. The lcexcess signal could therefore provide additional information as an end-member when applying mixing models to derive root water uptake depths and times, since $\delta^{2} \mathrm{H}$ and lc-excess do not necessarily correlate. So far, usually either $\delta^{2} \mathrm{H}$ or $\delta^{18} \mathrm{O}$, but not lc-excess are being considered to delineate water sources of the vegetation (Rothfuss and Javaux, 2017). In line with the call for a higher temporal resolution of soil water isotope sampling (Berry et al., 2017), the highly dynamic isotopic signal during the transition between the dormant and growing seasons underlines the importance of not limiting the soil water isotope sampling to a few sampling campaigns (usually $n \leq 3$ in Brooks et al., 2010; Evaristo et al., 2016; Goldsmith et al., 2012), when investigating root water uptake patterns. In the light of recent studies dealing with potential water sources of vegetation that showed how variable the plant water isotopic signal can be over a year (Hervé-Fernández et al., 2016; McCutcheon et al., 2016), a proper understanding of the temporal variability of the potential water sources (i.e., bulk soil water, groundwater, stream water) appears to be critical.

\subsection{Vegetation affects critical zone evaporation losses}

The vegetation was the main reason for differences in the soil water evaporation signal between the four study sites. While we limited the study to one soil type, we still saw differences between the soils in terms of their organic matter content leading to different soil water storage capacity. However, these differences in water storage capacity seemed to only influence the evaporation signal during periods of high precipitation input, when evaporation is already likely to be low (Fig. 6). The aspect and exposition of the slopes did not affect the soil water evaporation signal, which probably can be explained by the low angle $\left(4^{\circ}\right)$ for the north- and south-facing slopes at our site. Differences in net radiation for the two studied slopes were found to be small with the north-facing slope receiving about $4 \%$ less radiation than the south-facing slope between April and October (Ala-Aho et al., 2017).

The significant differences of the SW lc-excess in soils beneath Scots pine and heather are mainly due to the differences of the vegetation structure. The heather forms a dense soil cover just about $20 \mathrm{~cm}$ above the ground with an understory of mosses and lichens. Thus, the vegetation shades most of the soil and generates a microclimate with little direct exchange between soil vapor and atmospheric vapor. The soil climatic conditions beneath heather are therefore characterized by higher relative humidity and less radiation input than for the soils beneath Scots pine. In addition, the soils beneath the Scots pine are not densely vegetated by understory, which allows for more open exchange between soil vapor and atmospheric vapor at the forested sites. A similar conclusion of microclimatic conditions driving the differences in the evaporation signal was drawn by Midwood et al. (1998), who also reported a higher isotopic enrichment of soil surface soil waters under groves and woody clusters than under grassland.

The fractionation signal was shown to be more pronounced for evaporation losses from drier soils compared to wetter soils (Allison et al., 1983; Barnes and Allison, 1988). 
Higher canopy storage, higher interception losses and reduced net precipitation in the forested stands, where throughfall is about $47 \%$ of precipitation, compared to the heather with throughfall being about $35 \%$ of precipitation (Braun, 2015) will influence the GWC of the soils beneath the two vegetation types. The higher transpiration rates of the trees (Wang et al., 2017) compared to the heather further influences the soil moisture dynamics, leading to significantly lower GWC in the forested sites. In consequence, soil evaporation taking place from the drier soils beneath Scots pine will result in higher evaporation fractionation than for soil evaporation from soils beneath heather.

The evaporation estimates are limited to the period of the highest evaporation fluxes in the Bruntland Burn and are likely to be lower than what we present, since we relate the isotopic enrichment to the long-term average input signal in our calculations. However, the assumption of relating the enrichment to the average input seems to be valid, since we have seen the steady state balance of unfractionated input and kinetic fractionation due soil evaporation during the summer months. Nevertheless, detailed estimates of the evaporative fluxes require transient modeling of all water fluxes (i.e., precipitation, transpiration, evaporation, recharge) and their isotopic composition, which will be subject of future work. Potential transient numerical modeling approaches that account for isotopic fractionation of the soil water isotopes are available (Braud et al., 2005; Rothfuss et al., 2012; Mueller et al., 2014).

The frequently measured soil water isotope data we have presented and the inherent evaporation signal can help to calibrate or benchmark the representation of soil-vegetationatmosphere interactions in tracer-aided hydrological modeling from the plot (Rothfuss et al., 2012; Sprenger et al., $2016 b$ ) to the catchment scale (Soulsby et al., 2015; van Huijgevoort et al., 2016). So far, the isotopic composition of mobile water has been used to better constrain semi-distributed models (Birkel et al., 2014; van Huijgevoort et al., 2016). Including the isotopes of the bulk soil water, could allow for an improved conceptualization of the soil-plant-atmosphere interface, which is crucial for an adequate representation of evaporation and transpiration. Especially the marked differences of the evaporation signal within the first few centimeters of the soil depth will significantly affect the age distribution of transpiration (Sprenger et al., 2016c), evaporation (Soulsby et al., 2016a) or evapotranspiration (Harman, 2015; Queloz et al., 2015; van Huijgevoort et al., 2016).

\section{Conclusions}

Our study provides a unique insight into the soil water stable isotope dynamics in podzolic soils under different vegetation types at a northern latitude site. We showed that, despite a relatively low energy environment in the Scottish Highlands, the temporal variability of soil water isotopic enrich- ment was driven by changes of soil evaporation over the year. The monthly frequency of the soil water isotope sampling corroborates the importance of covering transition periods in a climate with seasonally variable isotopic precipitation input signals and evaporative output fluxes. Missing sampling these periods of higher temporal variability in spring and autumn could pose problems when referring plant water isotopes to potential soil water sources or when using soil water isotopic information for calibrating hydrological models. Especially the delayed response of the soil water lc-excess to evaporation (hysteresis effect) provides valuable insight into how unfractionated precipitation input and kinetic fractionation due to soil evaporation both affect mixing processes in the upper layer of the critical zone. The fact that the evaporation signal generally disappears within the first $15 \mathrm{~cm}$ of the soil profile emphasizes the importance and the spatial scale of the processes taking place at the soil-vegetationatmosphere interface of the critical zone.

The vegetation type played a significant role for the evaporation losses, with a generally higher soil evaporation signal in the soil water isotopes beneath Scots pine than beneath heather. Notably, these differences - as indicated in the soil water lc-excess - remain limited to the top $15 \mathrm{~cm}$ of soil. The vegetation cover directly affected the evaporation losses with soil evaporation being twice as high as beneath Scots pine ( $10 \%$ of infiltrating water) compared to soils beneath heather (5\% of the infiltrating water) during the growing season.

The presented soil water isotope data covering the seasonal dynamics at high spatial resolution $(5 \mathrm{~cm}$ increments at four locations) will allow us to test efficiencies of soil physical models in simulating the water flow and transport in the critical zone (as called by for Vereecken, 2016). The data can further provide a basis to benchmark hydrological models for a more realistic representation of the celerities and velocities when simulating water fluxes and their ages within catchments (McDonnell and Beven, 2014).

Data availability. The data is available upon request.

\section{The Supplement related to this article is available online at https://doi.org/10.5194/hess-21-3839-2017- supplement.}

Author contributions. DT, CS, and MS established the sampling design together, MS conducted the field and laboratory work and statistical analysis, all authors were involved in the data interpretation, MS prepared the manuscript with contributions from both co-authors.

Competing interests. The authors declare that they have no conflict of interest. 
Acknowledgements. We are thankful for the support by Audrey Innes during all laboratory work. We further thank Jonathan Dick for running the isotope analysis of precipitation samples and Annette C. Raffan for her support in the soil texture analysis. We would also like to thank the European Research Council (ERC, project GA 335910 VeWa) for funding.

Edited by: Hilary McMillan

Reviewed by: two anonymous referees

\section{References}

Adomako, D., Maloszewski, P., Stumpp, C., Osae, S., and Akiti, T. T.: Estimating groundwater recharge from water isotope $\left(\delta^{2} \mathrm{H}, \delta^{18} \mathrm{O}\right)$ depth profiles in the Densu River basin, Ghana, Hydrolog. Sci. J., 55, 1405-1416, https://doi.org/10.1080/02626667.2010.527847, 2010.

Ala-aho, P., Tetzlaff, D., McNamara, J. P., Laudon, H., and Soulsby, C.: Using isotopes to constrain water flux and age estimates in snow-influenced catchments using the STARR (Spatially distributed Tracer-Aided Rainfall-Runoff) model, Hydrol. Earth Syst. Sci. Discuss., https://doi.org/10.5194/hess-2017-106, in review, 2017.

Allison, G., Barnes, C., and Hughes, M.: The distribution of deuterium and ${ }^{18} \mathrm{O}$ in dry soils 2. Experimental, J. Hydrol., 64, 377397, https://doi.org/10.1016/0022-1694(83)90078-1, 1983.

Ball, D. F.: Loss-on-ignition as an estimate of organic matter and organic carbon in non-calcareous soils, J. Soil Sci., 15, 84-92, https://doi.org/10.1111/j.1365-2389.1964.tb00247.x, 1964.

Barnes, C. and Allison, G.: The distribution of deuterium and ${ }^{18} \mathrm{O}$ in dry soils: 1 . Theory, J. Hydrol., 60, 141-156, https://doi.org/10.1016/0022-1694(83)90018-5, 1983.

Barnes, C. and Allison, G.: Tracing of water movement in the unsaturated zone using stable isotopes of hydrogen and oxygen, J. Hydrol., 100, 143-176, https://doi.org/10.1016/00221694(88)90184-9, 1988.

Berry, Z. C., Evaristo, J., Moore, G., Poca, M., Steppe, K., Verrot, L., Asbjornsen, H., Borma, L. S., Bretfeld, M., Hervé-Fernández, P., Seyfried, M., Schwendenmann, L., Sinacore, K., de Wispelaere, L., and McDonnell, J.: The two water worlds hypothesis: Addressing multiple working hypotheses and proposing a way forward, Ecohydrol., https://doi.org/10.1002/eco.1843, online first, 2017.

Bertrand, G., Masini, J., Goldscheider, N., Meeks, J., Lavastre, V., Celle-Jeanton, H., Gobat, J.-M., and Hunkeler, D.: Determination of spatiotemporal variability of tree water uptake using stable isotopes $\left(\delta^{18} \mathrm{O}, \delta^{2} \mathrm{H}\right)$ in an alluvial system supplied by a highaltitude watershed, Pfyn forest, Switzerland, Ecohydrol., 7, 319333, https://doi.org/10.1002/eco.1347, 2012.

Birkel, C., Soulsby, C., and Tetzlaff, D.: Developing a consistent process-based conceptualization of catchment functioning using measurements of internal state variables, Water Resour. Res., 50, 3481-3501, https://doi.org/10.1002/2013WR014925, 2014.

Braud, I., Bariac, T., Gaudet, J. P., and Vauclin, M.: SiSPATIsotope, a coupled heat, water and stable isotope (HDO and $\mathrm{H} 2{ }^{18} \mathrm{O}$ ) transport model for bare soil. Part I. Model description and first verifications, J. Hydrol., 309, 277-300, https://doi.org/10.1016/j.jhydrol.2004.12.013, 2005.
Braun, H.: Influence of vegetation on precipitation partitioning and isotopic composition in northern upland catchments, Master's Thesis, Professur für Hydrologie, Albert-Ludwigs-Universität Freiburg i. Br., 106 pp., 2015.

Brooks, J. R., Barnard, H. R., Coulombe, R., and McDonnell, J. J.: Ecohydrologic separation of water between trees and streams in a Mediterranean climate, Nat. Geosci., 3, 100-104, https://doi.org/10.1038/NGEO722, 2010.

Brooks, P. D., Chorover, J., Fan, Y., Godsey, S. E., Maxwell, R. M., McNamara, J. P., and Tague, C.: Hydrological partitioning in the critical zone: Recent advances and opportunities for developing transferrable understanding of water cycle dynamics, Water Resour. Res., 51, 6973-6987, https://doi.org/10.1002/2015WR017039, 2015.

Carrer, G. E., Rousseau, A. N., Jutras, S., and Fossey, M.: Assessment of the impact of pools on the water isotopic signature of a boreal patterned peatland, Hydrol. Process., 30, 1292-1307, https://doi.org/10.1002/hyp.10715, 2016.

Craig, H. and Gordon, L. I.: Deuterium and oxygen 18 variations in the ocean and the marine atmosphere, in: Stable Isotopes in Oceanographic Studies and Paleotemperatures, edited by: Tongiorgi, E., Stable Isotopes in Oceanographic Studies and Paleotemperatures, Spoleto, Italy, Laboratorio di Geologica Nucleare, Pisa, Italy, 9-130, 1965.

Craig, H., Gordon, L. I., and Horibe, Y.: Isotopic exchange effects in the evaporation of water: 1. Low-temperature experimental results, J. Geophys. Res., 68, 5079-5087, https://doi.org/10.1029/JZ068i017p05079, 1963.

Dansgaard, W.: Stable isotopes in precipitation, Tellus, 16, 436468, https://doi.org/10.1111/j.2153-3490.1964.tb00181.x, 1964.

Dawson, T. E. and Ehleringer, J. R.: Streamside trees that do not use stream water, Nature, 350, 335-337, https://doi.org/10.1038/350335a0, 1991.

Dunn, S. M. and Mackay, R.: Spatial variation in evapotranspiration and the influence of land use on catchment hydrology, J. Hydrol., 171, 49-73, https://doi.org/10.1016/0022-1694(95)027336, 1995.

Ehleringer, J. R. and Dawson, T. E.: Water uptake by plants: perspectives from stable isotope composition, Plant Cell Environ., 15, 1073-1082, https://doi.org/10.1111/j.13653040.1992.tb01657.x, 1992.

Evaristo, J., Jasechko, S., and McDonnell, J. J.: Global separation of plant transpiration from groundwater and streamflow, Nature, 525, 91-94, https://doi.org/10.1038/nature14983, 2015.

Evaristo, J., McDonnell, J. J., Scholl, M. A., Bruijnzeel, L. A., and Chun, K. P.: Insights into plant water uptake from xylemwater isotope measurements in two tropical catchments with contrasting moisture conditions, Hydrol. Process., 30, 3210-3227, https://doi.org/10.1002/hyp.10841, 2016.

Foley, J. A., Defries, R., Asner, G. P., Barford, C., Bonan, G., Carpenter, S. R., Chapin, F. S., Coe, M. T., Daily, G. C., Gibbs, H. K., Helkowski, J. H., Holloway, T., Howard, E. A., Kucharik, C. J., Monfreda, C., Patz, J. A., Prentice, I. C., Ramankutty, N., and Snyder, P. K.: Global consequences of land use, Science, 309, 570-574, https://doi.org/10.1126/science.1111772, 2005.

Gaj, M., Beyer, M., Koeniger, P., Wanke, H., Hamutoko, J., and Himmelsbach, T.: In situ unsaturated zone water stable isotope $\left({ }^{2} \mathrm{H}\right.$ and $\left.{ }^{18} \mathrm{O}\right)$ measurements in semi-arid environments: 
a soil water balance, Hydrol. Earth Syst. Sci., 20, 715-731, https://doi.org/10.5194/hess-20-715-2016, 2016.

Gaj, M., Kaufhold, S., Koeniger, P., Beyer, M., Weiler, M., and Himmelsbach, T.: Mineral mediated isotope fractionation of soil water, Rapid Commun. Mass Sp., 31, 269-280, https://doi.org/10.1002/rcm.7787, 2017a.

Gaj, M., Kaufhold, S., and McDonnell, J. J.: Potential limitation of cryogenic vacuum extractions and spiked experiments, Rapid Commun. Mass Sp., 31, 821-823, https://doi.org/10.1002/rcm.7850, 2017b.

Garvelmann, J., Külls, C., and Weiler, M.: A porewater-based stable isotope approach for the investigation of subsurface hydrological processes, Hydrol. Earth Syst. Sci., 16, 631-640, https://doi.org/10.5194/hess-16-631-2012, 2012.

Gat, J. R. and Levy, Y.: Isotope hydrology of inland sabkhas in the Bardawil area, Sinai, Limnol. Oceanogr., 23, 841-850, https://doi.org/10.4319/lo.1978.23.5.0841, 1978.

Gee, G. W. and Bauder, J. W.: Particle-size Analysis, in: Methods of Soil Analysis: Part 1- Physical and Mineralogical Methods, edited by: Klute, A., SSSA Book Series, American Society of Agronomy, Madison, WI, 383-411, 1986.

Geris, J., Tetzlaff, D., McDonnell, J., Anderson, J., Paton, G., and Soulsby, C.: Ecohydrological separation in wet, low energy northern environments?: A preliminary assessment using different soil water extraction techniques, Hydrol. Process., 29, 51395152, https://doi.org/10.1002/hyp.10603, 2015a.

Geris, J., Tetzlaff, D., McDonnell, J., and Soulsby, C.: The relative role of soil type and tree cover on water storage and transmission in northern headwater catchments, Hydrol. Process., 29, 18441860, https://doi.org/10.1002/hyp.10289, 2015b.

Geris, J., Tetzlaff, D., McDonnell, J. J., and Soulsby, C.: Spatial and temporal patterns of soil water storage and vegetation water use in humid northern catchments, Sci. Total Environ., 595, 486-493, https://doi.org/10.1016/j.scitotenv.2017.03.275, 2017.

Gerke, H. H. and van Genuchten, M. T.: A dual-porosity model for simulating the preferential movement of water and solutes in structured porous media, Water Resour. Res., 29, 305-319, https://doi.org/10.1029/92WR02339, 1993.

Gibson, J. J. and Reid, R.: Water balance along a chain of tundra lakes: A 20-year isotopic perspective, J. Hydrol., 519, 2148 2164, https://doi.org/10.1016/j.jhydrol.2014.10.011, 2014.

Gibson, J. J., Price, J. S., Aravena, R., Fitzgerald, D. F., and Maloney, D.: Runoff generation in a hypermaritime bog-forest upland, Hydrol. Process., 14, 2711-2730, https://doi.org/10.1002/1099-1085(20001030)14:15<2711:AIDHYP88>3.0.CO;2-2, 2000.

Gibson, J. J., Birks, S. J., and Edwards, T. W. D.: Global prediction of $\delta \mathrm{A}$ and $\delta 2 \mathrm{H}-\delta 18 \mathrm{O}$ evaporation slopes for lakes and soil water accounting for seasonality, Global Biogeochem. Cy., 22, GB2031, https://doi.org/10.1029/2007GB002997, 2008.

Goldsmith, G. R., Muñoz-Villers, L. E., Holwerda, F., McDonnell, J. J., Asbjornsen, H., and Dawson, T. E.: Stable isotopes reveal linkages among ecohydrological processes in a seasonally dry tropical montane cloud forest, Ecohydrol., 5, 779-790, https://doi.org/10.1002/eco.268, 2012.

Gonfiantini, R.: Environmental isotopes in lake studies, in: The Terrestrial Environment, B: Handbook of Environmental Isotope Geochemistry, edited by: Fritz, P. and Fontes, J. C., Elsevier, Amsterdam, 113-168, 1986.
Gouet-Kaplan, M., Arye, G., and Berkowitz, B.: Interplay between resident and infiltrating water: Estimates from transient water flow and solute transport, J. Hydrol., 458-459, 40-50, https://doi.org/10.1016/j.jhydrol.2012.06.026, 2012.

Gralher, B., Herbstritt, B., Weiler, M., Wassenaar, L. I., and Stumpp, C.: Correcting laser-based water stable isotope readings biased by carrier gas changes, Environ. Sci. Technol., 50, 7074-7081, https://doi.org/10.1021/acs.est.6b01124, 2016.

Harman, C. J.: Time-variable transit time distributions and transport: Theory and application to storage-dependent transport of chloride in a watershed, Water Resour. Res., 51, 1-30, https://doi.org/10.1002/2014WR015707, 2015.

Hendry, M. J., Schmeling, E., Wassenaar, L. I., Barbour, S. L., and Pratt, D.: Determining the stable isotope composition of pore water from saturated and unsaturated zone core: improvements to the direct vapour equilibration laser spectrometry method, Hydrol. Earth Syst. Sci., 19, 4427-4440, https://doi.org/10.5194/hess-19-4427-2015, 2015.

Hervé-Fernández, P., Oyarzún, C., Brumbt, C., Huygens, D., Bodé, S., Verhoest, N. E. C., and Boeckx, P.: Assessing the "two water worlds" hypothesis and water sources for native and exotic evergreen species in south-central Chile, Hydrol. Process., 30, 4227-4241, https://doi.org/10.1002/hyp.10984, 2016.

Heße, F., Zink, M., Kumar, R., Samaniego, L., and Attinger, S.: Spatially distributed characterization of soil-moisture dynamics using travel-time distributions, Hydrol. Earth Syst. Sci., 21, 549570, https://doi.org/10.5194/hess-21-549-2017, 2017.

Horita, J. and Wesolowski, D. J.: Liquid-vapor fractionation of oxygen and hydrogen isotopes of water from the freezing to the critical temperature, Geochim. Cosmochim. Ac., 58, 3425-3437, https://doi.org/10.1016/0016-7037(94)90096-5, 1994.

Hudson, B. D.: Soil organic matter and available water capacity, J. Soil Water Conserv., 49, 189-194, 1994.

Isokangas, E., Rossi, P. M., Ronkanen, A.-K., Marttila, H., Rozanski, K., and Kløve, B.: Quantifying spatial groundwater dependence in peatlands through a distributed isotope mass balance approach, Water Resour. Res., 53, 2524-2541, https://doi.org/10.1002/2016WR019661, 2017.

Jackson, R. B., Canadell, J., Ehleringer, J. R., Mooney, H. A., Sala, O. E., and Schulze, E. D.: A global analysis of root distributions for terrestrial biomes, Oecologia, 108, 389-411, https://doi.org/10.1007/BF00333714, 1996.

Javaux, M., Rothfuss, Y., Vanderborght, J., Vereecken, H., and Bruggemann, N.: Isotopic composition of plant water sources, Nature, 536, E1-3, https://doi.org/10.1038/nature18946, 2016.

Kirchner, J. W., Tetzlaff, D., and Soulsby, C.: Comparing chloride and water isotopes as hydrological tracers in two Scottish catchments, Hydrol. Process., 24, 1631-1645, https://doi.org/10.1002/Hyp.7676, 2010.

Kool, D., Agam, N., Lazarovitch, N., Heitman, J., Sauer, T., and Ben-Gal, A.: A review of approaches for evapotranspiration partitioning, Agr. Forest Meteorol., 184, 56-70, https://doi.org/10.1016/j.agrformet.2013.09.003, 2014.

Landwehr, J. M. and Coplen, T. B.: Line-conditioned excess: a new method for characterizing stable hydrogen and oxygen isotope ratios in hydrologic systems, in: International Conference on Isotopes in Environmental Studies, Aquatic Forum, Monte-Carlo, Monaco, 25-29 October 2004, IAEA, Vienna, 132-135, 2006. 
Landwehr, J. M., Coplen, T. B., and Stewart, D. W.: Spatial, seasonal, and source variability in the stable oxygen and hydrogen isotopic composition of tap waters throughout the USA, Hydrol. Process., 28, 5382-5422, https://doi.org/10.1002/hyp.10004, 2014.

McCutcheon, R. J., McNamara, J. P., Kohn, M. J., and Evans, S. L.: An Evaluation of the Ecohydrological Separation Hypothesis in a Semiarid Catchment, Hydrol. Process., 31, 783-799, https://doi.org/10.1002/hyp.11052, 2016.

McDonnell, J. J. and Beven, K.: Debates-The future of hydrological sciences: A (common) path forward? A call to action aimed at understanding velocities, celerities and residence time distributions of the headwater hydrograph, Water Resour. Res., 50, 5342-5350, https://doi.org/10.1002/2013WR015141, 2014.

Midwood, A. J., Boutton, T. W., Archer, S. R., and Watts, S. E.: Water use by woody plants on contrasting soils in a savanna parkland: assessment with $\delta^{2} \mathrm{H}$ and $\delta^{18} \mathrm{O}$, Plant Soil, 205, 1324, https://doi.org/10.1023/A:1004355423241, 1998.

Mioduszewski, J. R., Rennermalm, A. K., Robinson, D. A., and Mote, T. L.: Attribution of snowmelt onset in Northern Canada, J. Geophys. Res.-Atmos., 119, 9638-9653, https://doi.org/10.1002/2013JD021024, 2014.

Mueller, M. H., Alaoui, A., Kuells, C., Leistert, H., Meusburger, K., Stumpp, C., Weiler, M., and Alewell, C.: Tracking water pathways in steep hillslopes by $\delta^{18} \mathrm{O}$ depth profiles of soil water, J. Hydrol., 519, 340-352, https://doi.org/10.1016/j.jhydrol.2014.07.031, 2014.

Newberry, S. L., Prechsl, U. E., Pace, M., and Kahmen, A.: Tightly bound soil water introduces isotopic memory effects on mobile and extractable soil water pools, Isot. Environ. Healt. S., 1-14, https://doi.org/10.1080/10256016.2017.1302446, 2017.

Oerter, E. and Bowen, G.: In situ monitoring of $\mathrm{H}$ and $\mathrm{O}$ stable isotopes in soil water reveals ecohydrologic dynamics in managed soil systems, Ecohydrol., 10, e1841, https://doi.org/10.1002/eco.1841, 2017.

Oerter, E., Finstad, K., Schaefer, J., Goldsmith, G. R., Dawson, T., and Amundson, R.: Oxygen isotope fractionation effects in soil water via interaction with cations $(\mathrm{Mg}, \mathrm{Ca}, \mathrm{K}, \mathrm{Na})$ adsorbed to phyllosilicate clay minerals, J. Hydrol., 515, 1-9, https://doi.org/10.1016/j.jhydrol.2014.04.029, 2014.

Or, D., Lehmann, P., Shahraeeni, E., and Shokri, N.: Advances in Soil Evaporation Physics - A Review, Vadose Zone J., 12, 1-16, https://doi.org/10.2136/vzj2012.0163, 2013.

Orlowski, N., Breuer, L., and McDonnell, J. J.: Critical issues with cryogenic extraction of soil water for stable isotope analysis, Ecohydrol., 9, 3-10, https://doi.org/10.1002/eco.1722, 2016.

Queloz, P., Carraro, L., Benettin, P., Botter, G., Rinaldo, A., and Bertuzzo, E.: Transport of fluorobenzoate tracers in a vegetated hydrologic control volume: 2. Theoretical inferences and modeling, Water Resour. Res., 51, 2793-2806, https://doi.org/10.1002/2014WR016508, 2015.

Rees, R. M., Black, H., Chapman, S. J., Clayden, H., Edwards, A. C., and Waldron, S.: Loss of soil organic matter, in: The State of Scotland's Soil. Natural Scotland, edited by: Dobbie, K. E., Bruneau, P., and Towers, W., available at: www.sepa.org.uk/land/ land_publications.aspx (last access: 24 July 2017), 23-34, 2011.

Renner, M., Hassler, S. K., Blume, T., Weiler, M., Hildebrandt, A., Guderle, M., Schymanski, S. J., and Kleidon, A.: Dominant controls of transpiration along a hillslope transect inferred from eco- hydrological measurements and thermodynamic limits, Hydrol. Earth Syst. Sci., 20, 2063-2083, https://doi.org/10.5194/hess-202063-2016, 2016.

Rinaldo, A., Beven, K. J., Bertuzzo, E., Nicotina, L., Davies, J., Fiori, A., Russo, D., and Botter, G.: Catchment travel time distributions and water flow in soils, Water Resour. Res., 47, W07537, https://doi.org/10.1029/2011wr010478, 2011.

Rothfuss, Y. and Javaux, M.: Reviews and syntheses: Isotopic approaches to quantify root water uptake: a review and comparison of methods, Biogeosciences, 14, 2199-2224, https://doi.org/10.5194/bg-14-2199-2017, 2017.

Rothfuss, Y., Braud, I., Le Moine, N., Biron, P., Durand, J.L., Vauclin, M., and Bariac, T.: Factors controlling the isotopic partitioning between soil evaporation and plant transpiration: Assessment using a multi-objective calibration of SiSPATIsotope under controlled conditions, J. Hydrol., 442-443, 75-88, https://doi.org/10.1016/j.jhydrol.2012.03.041, 2012.

Rothfuss, Y., Merz, S., Vanderborght, J., Hermes, N., Weuthen, A., Pohlmeier, A., Vereecken, H., and Brüggemann, N.: Long-term and high-frequency non-destructive monitoring of water stable isotope profiles in an evaporating soil column, Hydrol. Earth Syst. Sci., 19, 4067-4080, https://doi.org/10.5194/hess-19-40672015, 2015.

Schwärzel, K., Menzer, A., Clausnitzer, F., Spank, U., Häntzschel, J., Grünwald, T., Köstner, B., Bernhofer, C., and Feger, K.-H.: Soil water content measurements deliver reliable estimates of water fluxes: A comparative study in a beech and a spruce stand in the Tharandt forest (Saxony, Germany), Agr. Forest Meteorol., 149, 1994-2006, https://doi.org/10.1016/j.agrformet.2009.07.006, 2009.

Shen, M., Tang, Y., Chen, J., Yang, X., Wang, C., Cui, X., Yang, Y., Han, L., Le Li, Du, J., Zhang, G., and Cong, N.: Earlier-season vegetation has greater temperature sensitivity of spring phenology in northern hemisphere, PloS one, 9, e88178, https://doi.org/10.1371/journal.pone.0088178, 2014.

Soulsby, C., Tetzlaff, D., van den Bedem, N., Malcolm, I. A., Bacon, P. J., and Youngson, A. F.: Inferring groundwater influences on surface water in montane catchments from hydrochemical surveys of springs and streamwaters, J. Hydrol., 333, 199-213, https://doi.org/10.1016/j.jhydrol.2006.08.016, 2007.

Soulsby, C., Birkel, C., Geris, J., Dick, J., Tunaley, C., and Tetzlaff, D.: Stream water age distributions controlled by storage dynamics and nonlinear hydrologic connectivity: Modeling with high-resolution isotope data, Water Resour. Res., 51, 7759-7776, https://doi.org/10.1002/2015WR017888, 2015.

Soulsby, C., Birkel, C., and Tetzlaff, D.: Characterizing the age distribution of catchment evaporative losses, Hydrol. Process., 30, 1308-1312, https://doi.org/10.1002/hyp.10751, 2016a.

Soulsby, C., Bradford, J., Dick, J., McNamara, J. P., Geris, J., Lessels, J., Blumstock, M., and Tetzlaff, D.: Using geophysical surveys to test tracer-based storage estimates in headwater catchments, Hydrol. Process., 30, 4434-4445, https://doi.org/10.1002/hyp.10889, 2016b.

Sprenger, M., Herbstritt, B., and Weiler, M.: Established methods and new opportunities for pore water stable isotope analysis, Hydrol. Process., 29, 5174-5192, https://doi.org/10.1002/hyp.10643, 2015a.

Sprenger, M., Volkmann, T. H. M., Blume, T., and Weiler, M.: Estimating flow and transport parameters in the unsaturated zone 
with pore water stable isotopes, Hydrol. Earth Syst. Sci., 19, 2617-2635, https://doi.org/10.5194/hess-19-2617-2015, 2015b.

Sprenger, M., Erhardt, M., Riedel, M., and Weiler, M.: Historical tracking of nitrate in contrasting vineyards using water isotopes and nitrate depth profiles, Agr. Ecosyst. Environ., 222, 185-192, https://doi.org/10.1016/j.agee.2016.02.014, 2016a.

Sprenger, M., Leistert, H., Gimbel, K., and Weiler, M.: Illuminating hydrological processes at the soil-vegetation-atmosphere interface with water stable isotopes, Rev. Geophys., 54, 674-704, https://doi.org/10.1002/2015RG000515, 2016b.

Sprenger, M., Seeger, S., Blume, T., and Weiler, M.: Travel times in the vadose zone: variability in space and time, Water Resour. Res., 52, 5727-5754, https://doi.org/10.1002/2015WR018077, 2016c.

Sprenger, M., Tetzlaff, D., and Soulsby, C.: No influence of $\mathrm{CO}_{2}$ on stable isotope analyses of soil waters with OA-ICOS, Rapid Commun. Mass Sp., 31, 430-436, https://doi.org/10.1002/rcm.7815, 2017a.

Sprenger, M., Tetzlaff, D., Tunaley, C., Dick, J., and Soulsby, C.: Evaporation fractionation in a peatland drainage network affects stream water isotope composition, Water Resour. Res., 53, 851866, https://doi.org/10.1002/2016WR019258, 2017 b.

Stumpp, C., Stichler, W., Kandolf, M., and Šimůnek, J.: Effects of Land Cover and Fertilization Method on Water Flow and Solute Transport in Five Lysimeters: A Long-Term Study Using Stable Water Isotopes, Vadose Zone J., 11, vzj2011.0075, https://doi.org/10.2136/vzj2011.0075, 2012.

Tetzlaff, D., Carey, S., Soulsby, C., Tetzlaff, D., Soulsby, C., Buttle, J., Capell, R., Carey, S. K., Laudon, H., McDonnell, J., McGuire, K., Seibert, J., and Shanley, J.: Catchments on the cusp? Structural and functional change in northern ecohydrology, Hydrol. Process., 27, 766-774, https://doi.org/10.1002/hyp.9700, 2013.

Tetzlaff, D., Birkel, C., Dick, J., Geris, J., and Soulsby, C.: Storage dynamics in hydropedological units control hillslope connectivity, runoff generation and the evolution of catchment transit time distributions, Water Resour. Res., 50, 969-985, https://doi.org/10.1002/2013WR014147, 2014.

Twining, J., Stone, D., Tadros, C., Henderson-Sellers, A., and Williams, A.: Moisture Isotopes in the Biosphere and Atmosphere (MIBA) in Australia: A priori estimates and preliminary observations of stable water isotopes in soil, plant and vapour for the Tumbarumba Field Campaign, Global Planet. Change, 51, 59-72, https://doi.org/10.1016/j.gloplacha.2005.12.005, 2006. van der Velde, Y., Heidbüchel, I., Lyon, S. W., Nyberg, L., Rodhe, A., Bishop, K., and Troch, P. A.: Consequences of mixing assumptions for time-variable travel time distributions, Hydrol. Process., 29, 3460-3474, https://doi.org/10.1002/hyp.10372, 2015.

van Genuchten, M. T. and Wierenga, P. J.: Mass transfer studies in sorbing porous media I. Analytical solutions, Soil Sci. Soc. Am. J., 40, 473-480, 1976.

van Huijgevoort, M. H. J., Tetzlaff, D., Sutanudjaja, E. H., and Soulsby, C.: Using high resolution tracer data to constrain water storage, flux and age estimates in a spatially distributed rainfall-runoff model, Hydrol. Process., 30, 4761-4778, https://doi.org/10.1002/hyp.10902, 2016.

Vereecken, H.: Modeling Soil Processes: Review, Key challenges and New Perspectives, Vadose Zone J., 15, 1-57, 2016.

Volkmann, T. H. M., Haberer, K., Gessler, A., and Weiler, M.: Highresolution isotope measurements resolve rapid ecohydrological dynamics at the soil-plant interface, New Phytol., 210, 839-849, https://doi.org/10.1111/nph.13868, 2016.

Wang, H., Tetzlaff, D., and Soulsby, C.: Assessing the environmental controls on Scots pine transpiration and the implications for water partitioning in a boreal headwater catchment, Agr. Forest Meteorol., 240-241, 58-66, https://doi.org/10.1016/j.agrformet.2017.04.002, 2017.

Wassenaar, L., Hendry, M., Chostner, V., and Lis, G.: High Resolution Pore Water $\delta^{2} \mathrm{H}$ and $\delta^{18} \mathrm{O}$ Measurements by $\mathrm{H}_{2} \mathrm{O}$ (liquid) $-\mathrm{H}_{2} \mathrm{O}$ (vapor) Equilibration Laser Spectroscopy, Environ. Sci. Technol., 42, 9262-9267, https://doi.org/10.1021/es802065s, 2008.

Welhan, J. and Fritz, P.: Evaporation pan isotopic behavior as an index of isotopic evaporation conditions, Geochim. Cosmochim. Ac., 41, 682-686, https://doi.org/10.1016/0016-7037(77)903064, 1977.

Werner, C. and Dubbert, M.: Resolving rapid dynamics of soilplant-atmosphere interactions, New Phytol., 210, 767-769, https://doi.org/10.1111/nph.13936, 2016.

Wershaw, R. L., Friedman, I., and Heller, S. J.: Hydrogen isotope fractionation of water passing through trees, in: Advances in Organic Geochemistry, edited by: Hobson, F. and Speers, M., Pergamon Press, New York, 55-67, 1966.

Zobel, R. W. and Waisel, Y.: A plant root system architectural taxonomy: A framework for root nomenclature, Plant Biosyst., 144, 507-512, https://doi.org/10.1080/11263501003764483, 2010. 